Article

\title{
Provenance of Bengal Shelf Sediments: 2. Petrology and Geochemistry of Sand
}

\author{
Eduardo Garzanti ${ }^{1, *} \mathbb{C}$, Giovanni Vezzoli ${ }^{1}$, Sergio Andò ${ }^{1}$, Mara Limonta ${ }^{1}$, Laura Borromeo ${ }^{1} \mathbb{C}$ \\ and Christian France-Lanord ${ }^{2}$ \\ 1 Laboratory for Provenance Studies, Department of Earth and Environmental Sciences, University of \\ Milano-Bicocca, 20126 Milano, Italy; giovanni.vezzoli@unimib.it (G.V.); sergio.ando@unimib.it (S.A.); \\ mara.limonta@unimib.it (M.L.); laura.borromeo@unimib.it (L.B.) \\ 2 Centre de Recherches Pétrographiques et Géochimiques, Université de Lorraine-CNRS, BP 20, \\ 54501 Vandoeuvre-lès-Nancy, France; cfl@crpg.cnrs-nancy.fr \\ * Correspondence: eduardo.garzanti@unimib.it; Tel.: +39-02-64482088
}

Received: 26 August 2019; Accepted: 12 October 2019; Published: 19 October 2019

\begin{abstract}
The Bangladesh lowlands are traversed by the largest sediment flux on the planet. Detritus generated mostly in Himalayan highlands and conveyed through the Ganga-Brahmaputra rivers and Meghna estuary reaches the Bay of Bengal, where it forms a composite deltaic system. This study integrates the vast existing database on Ganga-Brahmaputra sediments of all grain sizes from clay to sand with new petrographic, mineralogical, and geochemical data on estuarine and shallow-marine sands. A large spectrum of compositional signatures was used to: (i) assess the relative supply of the Ganga and Brahmaputra rivers to estuarine and shelfal sediments; (ii) define the compositional variability of estuarine sediments and the impact exerted by hydraulic sorting and climate-related chemical weathering on provenance signals; (iii) define the compositional variability of shelf sediments and the potential hydrodynamic segregation of fast-settling heavy minerals in coastal environments and of slow-settling platy micas on low-energy outer-shelf floors; (iv) consider the potential additional mud supply from the western subaerial part of the delta formerly built by the Ganga River; and (v) draw a preliminary mineralogical comparison between fluvio-deltaic sediments and turbidites of the Bengal-Nicobar deep-sea fan, thus tracing sediment dispersal across the huge sedimentary system extending from Tibet to the equatorial Indian Ocean. All investigated mineralogical and geochemical parameters, as well as $\mathrm{Sr}$ and $\mathrm{Nd}$ isotope ratios and clay-mineral assemblages, showed a clear prevalence in sediment supply from the Brahmaputra (60-70\%) over the Ganga (30-40\%). Heavy-mineral suites and $\mathrm{Sr}$ and $\mathrm{Nd}$ isotope fingerprints of Bengal shelf sediments are nearly identical to those of the Brahmaputra River and Meghna estuary, also because the Brahmaputra carries almost twice as many Ca-plagioclase grains and heavy minerals including epidote than the Ganga, and these minerals control the large majority of the $\mathrm{Sr}$ and $\mathrm{Nd}$ budgets. The experience gained in modern settings can be directly extrapolated only to the recent past, because sediments older than the late Pleistocene and buried more than a few hundred meters begin to lose less durable ferromagnesian minerals by selective chemical dissolution, which makes quantitative estimates progressively less robust in more deeply buried older strata.
\end{abstract}

Keywords: bulk-sediment petrography; bulk-sediment geochemistry; heavy minerals; selective entrainment; suspension sorting; chemical indices of weathering; sediment budgets; Brahmaputra River; Ganga River; Himalayan orogen 
"Idly my mind follows the sinuous sweep of the Padma roaming under a distant sky. On the further side of hers stretches the sand-bank, insensitive to the living world, defiant in its sublime inutility."

Rabindranath Tagore, Poems: 94

\section{Introduction}

The Ganga and Brahmaputra rivers drain the Himalayan orogen and join in Bangladesh to form the Meghna estuary, which represents the largest single entry point of detritus in the world oceans ([1,2]). More than 1 billion tons of sediment have reached the Bengal Sea each year through most of the Neogene. Sediment partly accumulates in the delta and partly bypasses the shelf to generate turbiditic currents that feed the Bengal-Nicobar Fan, the largest deep-sea cone on our planet $([3,4])$. The Bengal sediment system, which represents the focus of this study, is composed of an abandoned subaerial delta in the west, drained by tidal distributary channels and partially subject to erosion, and an actively prograding subaqueous delta that connects the estuary mouth with the Swatch of No Ground, the deep canyon through which detritus is conveyed toward the submarine fan ([5-7]).

This article is intended as complementary to previous studies carried out on both bedload and suspended-load sediments of the Ganga and Brahmaputra rivers in the proximal part of the sediment-routing system ([8-18]), and to the companion paper dedicated to the mineralogy of Bengal shelf mud ([19]). Our aim was to combine petrographic, heavy-mineral, and geochemical data on the entire range of size fractions from bedload sand to cohesive mud in order to investigate and wherever possible quantify how provenance signals are modified in transit from the subaerial fluvio-deltaic system to the subaqueous delta on the shelf and as far as the ocean floors. The thorough evaluation of the mineralogical variability associated with hydrodynamic sorting and other physical and chemical processes across deltaic and shallow-marine environments represents the fundamental pre-requisite to link the orogenic provenance signatures of Ganga and Brahmaputra sediments with the deep-sea sedimentary record ([20-23]).

A more accurate assessment of the relative amount of sediment supplied by the Ganga and Brahmaputra rivers to the Bay of Bengal is needed to unravel the interplay between tectonic and climatic processes that has controlled the evolution of the Himalayan orogen, and to circumscribe patterns of focused erosion associated with tectonic (e.g., rapid exhumation of the eastern Himalayan Syntaxis), climatic (e.g., impact of monsoon moisture from the Bay of Bengal on rain-drenched Himalayan foothills), or mixed tectonic/climatic processes (e.g., rain-shadow effect consequent to the recent rise of the Shillong Plateau in front of the Bhutan Himalaya).

\section{The Ganga-Brahmaputra Rivers and the Bengal Shelf}

The Ganga River is sourced from the Himalayan orogen and none of its tributaries reach into the Indus-Yarlung suture zone. The $\sim 10^{6} \mathrm{~km}^{2}$-wide drainage basin includes the central Himalayan thrust belt from northern India to Nepal $\left(\sim 0.17 \times 10^{6} \mathrm{~km}^{2}\right)$ and the northern part of the Indian shield $\left(\sim 0.35 \times 10^{6} \mathrm{~km}^{2}\right)$, almost half of it being represented by foreland-basin lowlands ([24,25]). Detritus is mostly derived from the sub-parallel tectonic domains forming the Himalayan orogen, which comprise the Paleozoic to Eocene sedimentary succession of the Tethys Himalaya ([26,27]), amphibolite-facies metasedimentary rocks of the Greater Himalaya including Lower Paleozoic granitoids and Miocene leucogranites at the top ([28,29]), Proterozoic orthogneisses and metasedimentary rocks of the Lesser Himalaya covered by Paleozoic to Cenozoic strata $([30,31])$, and Neogene foreland-basin siliciclastic rocks of the Sub-Himalaya ([32,33]). Major southern tributaries draining the Precambrian Indian shield and its sedimentary and Deccan Traps basaltic covers are the Chambal and Son rivers.

The $\sim 0.63 \times 10^{6} \mathrm{~km}^{2}$-wide Brahmaputra drainage basin includes in the upper catchment calc-alkaline batholiths and sedimentary rocks of the Lhasa block ([34]) and forearc-basin ophiolites, turbidites, and ophiolitic mélange exposed along the Yarlung Tsangpo suture ([35-37]) running from southern Tibet to Myanmar $\left(\sim 0.23 \times 10^{6} \mathrm{~km}^{2}\right.$; [38]). A large part of Brahmaputra sediment is derived 
from the eastern Himalayan syntaxis ([39]), where extreme erosion rates and huge sediment fluxes are produced by the combination of extraordinary river gradients with the large water discharge fueled by heavy summer-monsoon precipitation $([40,41])$. Right-bank (northern) tributaries joining the trunk river in the Assam plains drain the eastern Himalayan belt in Arunachal Pradesh, Bhutan, and Sikkim $\left(\sim 0.13 \times 10^{6} \mathrm{~km}^{2}\right.$; [42-44]), whereas left-bank (eastern and southern) tributaries drain Cenozoic turbidites of the Indo-Burman Ranges and Precambrian granitoid gneisses of the Shillong Plateau $\left(\sim 0.04 \times 10^{6} \mathrm{~km}^{2}\right)$. Between $40 \%$ and $70 \%$ of suspended load carried by the Brahmaputra River is estimated to be trapped in foreland-basin floodplains ([45]).

Estimates of total water discharge range from 380 to $590 \mathrm{~km}^{3} / \mathrm{a}$ for the Ganga and from 400 to $630 \mathrm{~km}^{3} / \mathrm{a}$ for the Brahmaputra, whereas suspended load is estimated to range widely from 316 to $729 \times 10^{6} \mathrm{t} / \mathrm{a}$ for the Ganga and from 402 to $1157 \times 10^{6} \mathrm{t} / \mathrm{a}$ for the Brahmaputra ([16,18,46-48]). The most commonly cited figures range 380-480 $\times 10^{6} \mathrm{t} / \mathrm{a}$ for the Ganga and 650-680 $\times 10^{6} \mathrm{t} / \mathrm{a}$ for the Brahmaputra, which implies that $\sim 60 \%$ of the sediment exported to the Bay of Bengal is contributed by the Brahmaputra and most of the remaining $40 \%$ by the Ganga ([17]). Bedload flux, however, is very difficult to estimate. Based on modeling of hydrodynamic conditions, a figure as low as $4 \times 10^{6} \mathrm{t} / \mathrm{a}(\sim 1 \%$ of total load) was proposed for the Ganga ([14]). Conversely, estimates of Himalayan denudation based on ${ }^{10} \mathrm{Be}$ cosmogenic radionuclides point to an average total sediment export $50 \%$ to $80 \%$ higher than suspended-load fluxes $\left(610 \pm 230 \times 10^{6} \mathrm{t} / \mathrm{a}\right.$ for the Ganga and 780-1430 $\times 10^{6} \mathrm{t} / \mathrm{a}$ for the Brahmaputra; $[16,18])$, a surplus partitioned in unknown proportion between bedload flux and floodplain sequestration.

The high Himalayan range exerts a considerable influence on the climate of the region, and hence on sediment fluxes funneled via the Meghna estuary to the Bengal shelf. During the summer monsoon, the mountains are exposed to heavy rainfall, which reaches peak values (up to $5 \mathrm{~m} / \mathrm{a}$ ) in two major belts running along the foot of the mountains and in correspondence to the major topographic step ([49]). As much as $96 \%$ of the sediment load ([48,50]) and $82 \%$ of the annual water flow ([51]) are estimated to be delivered during the monsoon season, when water discharge reaches $83,000 \mathrm{~m}^{3} / \mathrm{s}$ for the Ganga and $102,000 \mathrm{~m}^{3} / \mathrm{s}$ for the Brahmaputra $([47,52,53])$. Current velocity decreases with channel depth from $\sim 3$ to $\sim 2 \mathrm{~m} / \mathrm{s}$ in the Ganga $([8,14])$, whereas depth-averaged velocity reaches $3.5 \mathrm{~m} / \mathrm{s}$ for the Brahmaputra ([54]).

\section{The Bengal Delta and the Shelf}

The Ganga and Brahmaputra rivers join $\sim 200 \mathrm{~km}$ upstream of the coastline forming a $\sim 100 \mathrm{~km}$-long river tract named Padma (the name of the Ganga in Bangladesh). After receiving the Meghna River, which drains the Shillong Plateau and the frontal part of the Indo-Burman Ranges, this huge river system debouches into the Bengal Sea in the $\sim 100 \mathrm{~km}$ long, tide-dominated Lower Meghna estuary with four channels named, from west to east, Tetulia, Shahbazpur, Hatia, and Sandwip (Figure 1). To the west of the Meghna estuary lies the Sundarban mangrove forest, formed during progressive eastward migration of the Ganga during the late Holocene highstand ([55]).

Until the late 18th century, as shown in the map by Rennell [56] (Figure 19.4 in [54]), the Ganga discharged through the Tetulia channel, whereas the Brahmaputra flowed to the east of the Madhupur terrace and across the Sylhet basin to reach the sea joint with the Meghna River (Figure 1). This Old Brahmaputra (Burrampooter) course was progressively abandoned during catastrophic floods between the latest 18th century and the beginning of the 19th century, and the Ganga and Brahmaputra became eventually joined around 1830 ([57,58]).

The Ganga-Brahmaputra delta lies on an active plate-boundary and sits on the continent-ocean transition at the northern edge of the Indian plate, which is subducting under the Himalaya in the north and under the Tripura (Indo-Burman) fold-belt in the east ([5,59]). The delta has thus long been subjected to strong tectonic subsidence, which has determined an accumulation of $\sim 16 \mathrm{~km}$ of orogenic sediment since Paleocene collision between India and Asia $([3,60,61])$. Despite continuing subsidence ([62]; Figure 9 in [63]), huge sediment supply was sufficient to halt transgression during 
rapid sea-level rise in the early Holocene, and to initiate deltaic progradation at rates notably higher than most other deltas worldwide since $\sim 11 \mathrm{ka}$, leading to seaward coastal advance by $100-300 \mathrm{~km}$ over a $250 \mathrm{~km}$ wide front after maximum sea level was reached at 8-7 ka ([64]). In the last 6-5 ka, the lower delta plain west of the modern estuary was deposited as a Ganga-dominated delta, whereas Brahmaputra influence remained confined to the eastern area of the Meghna estuary and to the supratidal part of the delta (Figure 13 in [65]; Figure 9 in [55]). Active sedimentation has continued until today in the estuary area, where on average $7 \mathrm{~km}^{2}$ of new land have been added each year since $1792\left(4.4 \mathrm{~km}^{2} /\right.$ a since 1840) while the inactive western delta was undergoing tidal reworking and net erosion with as much as 3-4 km of shoreline retreat ([66]; Figure $2 \mathrm{~b}$ in [6]).

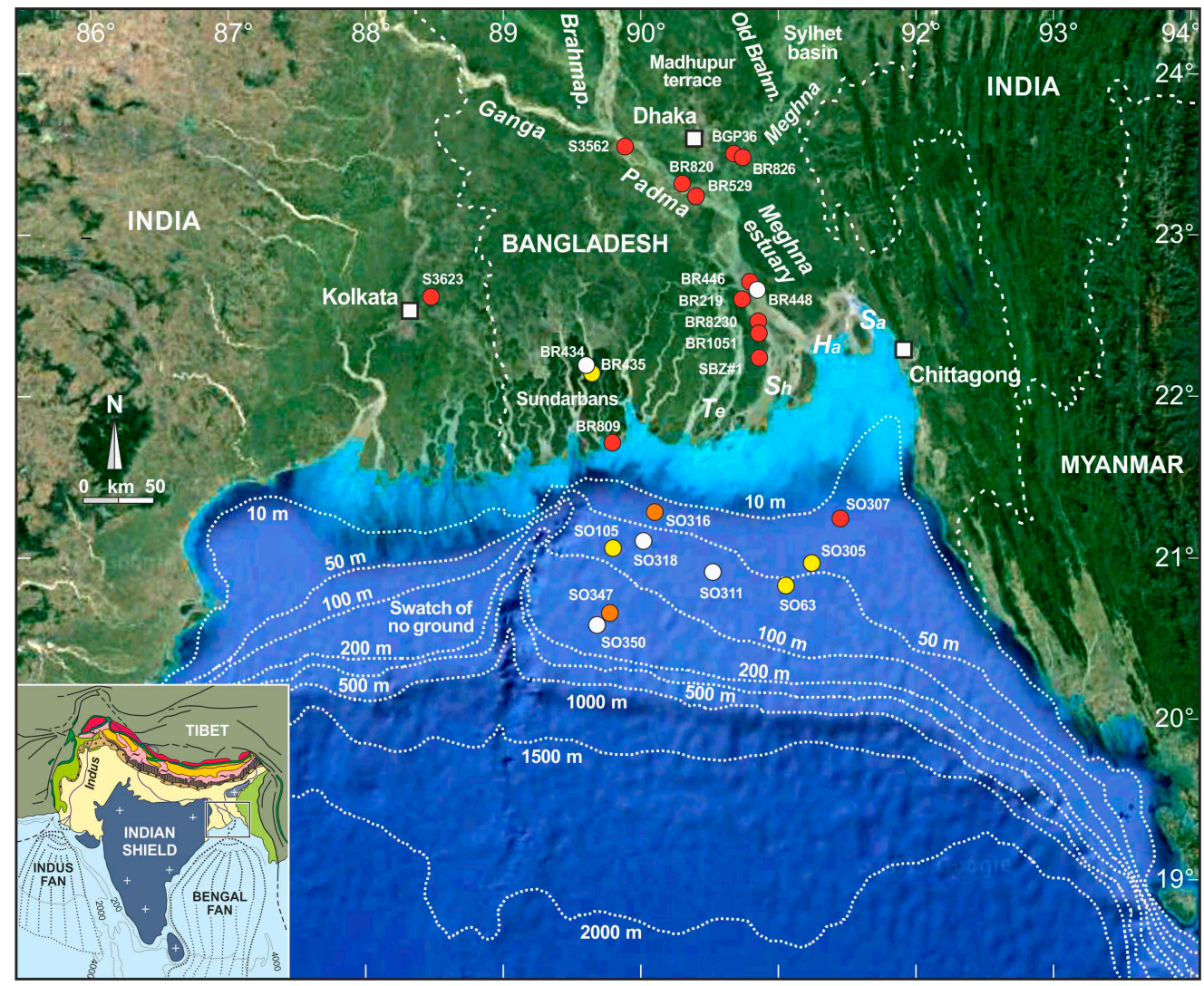

Figure 1. The subaerial and subaqueous delta formed by the Ganga and Brahmaputra rivers and prograding into the Bay of Bengal. Colored circles point at locations of the studied Padma, Meghna estuary, and shelfal sand (red), silty sand (orange), sandy silt (yellow), and silt (white) samples. Offshore sediments were collected during Sonne cruises SO93-3 and SO188-2 in February 1994 and July 2006. The four main channels of the estuary mouth are indicated (Te, Tetulia; Sh, Shahbazpur; Ha, Hatia; Sa, Sandwip).

Offshore, a large subaqueous delta is prograding seaward between the Hatia trough in the east and the Swatch of No Ground in the west, the gigantic submarine canyon that connected the Ganga-Brahmaputra mouth with the Bengal Fan during lowstands (Figure 1). The canyon deeply incised into the shelf, acts as a barrier for farther westward sediment transport and as a sink for approximately a third of fluvial sediment load ([5]). Beyond the estuary mouth, sandy topsets are wide and extend to $\sim 100 \mathrm{~km}$ offshore between water depths of $\sim 5 \mathrm{~m}$ and $15-30 \mathrm{~m}$ b.s.l. The slope steepens in delta-front foresets between water depths of 20-30 and $\sim 80 \mathrm{~m}$ b.s.l., where grain size decreases from very fine sand to fine silt ([67]). The outer shelf, extending between 80 and $150 \mathrm{~m}$ b.s.l. at the shelf edge, includes muddy prodelta bottomsets passing seaward to a discontinuous layer of palimpsest sand and 
mud containing biogenic debris, originally deposited in tidal-flat and delta-plain environments during the last glacial period and reworked during the early Holocene transgression $([68,69])$.

Tidal amplitude is $\sim 2 \mathrm{~m}$ in the Sundarbans to the west, where saline waters may penetrate inland by more than $100 \mathrm{~km}$, and then increases eastward in the Tetulia and Shahbazpur channels to reach $\sim 5 \mathrm{~m}$ in the Hatia and Sandwip channels ([65]). Tidal range decreases in the inner shelf from $0.8 \mathrm{~m}$ on topset beds to $0.5 \mathrm{~m}$ on foreset and bottomset beds and becomes negligible in the outer shelf ([70]). Agents of sediment transport and resuspension in the inner shelf are not only tides but largely tropical cyclones, which generate high waves that sweep the shelf mobilizing large amounts of sediment redeposited as graded beds ([68]). In the November 1970 typhoon, winds of $220 \mathrm{~km} / \mathrm{h}$ and a storm surge of 6-10 m recorded as far as $200 \mathrm{~km}$ inland resulted in 500,000 casualties in Bangladesh ([71,72]). Although the number and power of cyclones has seemingly decreased in the last decades, cyclones have continued to dominate sediment distribution across the shelf, with a main southwestward direction of transport toward the Swatch of No Ground ([7]).

Sedimentation rates have been assessed at $2-4 \mathrm{~cm} / \mathrm{a}$ on the delta plain in the Holocene ([73]), increasing to a maximum of $5-10 \mathrm{~cm} / \mathrm{a}$ on the delta front, and dropping to $0.3 \mathrm{~cm} / \mathrm{a}$ on the prodelta farther offshore $([68,74])$. Over the last centuries, the decline in monsoon precipitation contributed to a progressive decrease in the percentage of fluvial sediment load stored in the eastern part of the subaqueous delta, from $\sim 22 \%$ in the 19 th century, to $\sim 18 \%$ in the first half of the 19 th century, and to $11-17 \%$ thereafter. The depocentre is apparently shifting toward the western part of the subaqueous delta and to the Swatch of No Ground canyon, thus increasing the export as turbidity currents to the deep-sea fan $([67,75])$.

\section{Analytical Methods}

To investigate provenance of Bengal shelf sand and quantify the compositional differences between fluvial and marine sediments we analyzed the petrographic, heavy-mineral, and geochemical compositions of samples SO188_307VC 0-20,SO188_316VC 0-100, and SO188_347VC 280-300 (named SO307, SO316, and SO347 for brevity throughout the article (Figure 1), collected by vibrocorer on the Bengal shelf at water depths of 16, 19, and $126 \mathrm{~m}$ b.s.l. during Sonne cruise 188-2 in July 2006 ([76]), and of bedload samples BR446, BR8230, and BR1051 collected from the active channel bed at water depths between 10 and $17 \mathrm{~m}$ in the Meghna estuary during the full monsoon season in July 2004, early September 2008, and July 2010.

These new results allowed comparison with mineralogical and geochemical data on Bengal shelf mud illustrated in the companion paper by [19], with the previously obtained extensive mineralogical dataset on fluvial bedload and suspended load of the Ganga-Brahmaputra system illustrated in [12,13], and with our own data on sediment samples from the Padma River (S3562, BR820, and vertical profile BR524-BR529), the Meghna River (BGP36 and BR826), the Meghna estuary (BR219 and vertical profiles BR439-BR448), the delta, and the shelf. Bengal delta sediments were cored on land $20 \mathrm{~km}$ NNE of Kolkata (S3623; luminesce age 7.764 years, Andy Carter written communication, 2006) and on Bhola Island between the Tetulia and Shahbazpur channels (SBZ\#1), or collected from a tidal distributary channel (Pussur BR434, BR435) and from Katka beach in the Sundarbans (BR809). Samples SO93_63KL 3-7 and SO93_105KL 686-690 (named SO63 and SO105 for brevity throughout the article) were collected by piston corer on the Bengal shelf during Sonne cruise 93 in January 1994, at water depths of 66 and $80 \mathrm{~m}$ b.s.l. ([77]). Previously obtained results, including multiple-window petrographic and heavy-mineral data obtained separately for all significant size classes of two selected sand samples from the Padma River and Meghna estuary (S3562 collected during the dry season and BR446 collected during the wet monsoon season), and multiple-window heavy-mineral data on Meghna estuary shallow suspended load (sample BR448) and Bengal shelf sandy silt (sample SO63) allowed us to evaluate the compositional variability related to markedly seasonal transport, as well as various sources of error during sampling, sample treatment, and analysis. 
Statistical techniques used to illustrate our petrographic and heavy-mineral datasets include multidimensional scaling, which produces a map of points in which samples with similar mineralogical signature cluster closely together and dissimilar samples plot far apart $([78,79])$ and the compositional biplot ([80]). The biplot is a very efficient statistical/graphical tool that allows discrimination among multivariate observations (points) while shedding light on the mutual relationships among variables (rays). The length of each ray is proportional to the variance of the corresponding variable in the dataset. If the angle between two rays is close to $0^{\circ}, 90^{\circ}$ or $180^{\circ}$, then the corresponding variables are directly correlated, uncorrelated, or inversely correlated, respectively. Key compositional parameters for selected samples are summarized in Table 1. Full information on sampling locations (Table S1 and Google Earth ${ }^{\mathrm{TM}}$ file Bengalsand.kmz) and the complete petrographic (Table S2), heavy-mineral (Table S3), and geochemical datasets (Table S4) are provided in the Supplementary Materials.

\subsection{Petrography}

A quartered aliquot of each bulk sample was impregnated with araldite, cut into a standard thin section stained with alizarine red to distinguish dolomite and calcite, and analyzed by counting 400 or 450 points under the microscope (Gazzi-Dickinson method; [81]). Sand samples were classified according to the relative abundance of the three main groups of framework components ( $Q=$ quartz; F = feldspars; $L=$ lithic fragments), considered where exceeding 10\% QFL. According to standard use ([82,83]), the less abundant component goes first, the more abundant last (e.g., in a litho-feldspatho-quartzose sand Q > F > L > 10\% QFL; classification scheme after [84,85]). The average rank of metamorphic rock fragments was expressed by the metamorphic indices $\mathrm{MI}$ or $\mathrm{MI}^{*}$, ranging, respectively, from 0 (detritus from sedimentary and volcanic rocks) or 100 (detritus from very low-grade metamorphic rocks) to 500 (detritus from high-grade metamorphic rocks; [86]). The median grain size of sand samples was determined both by sieving and in thin section by ranking and visual comparison with standards of $\phi / 4$ classes prepared in our laboratory.

\subsection{Heavy Minerals}

From a split aliquot of the $>15 \mu \mathrm{m}$ size fraction obtained by wet sieving, heavy minerals were separated by centrifuging in Na-polytungstate $\left(2.90 \mathrm{~g} / \mathrm{cm}^{3}\right)$ and recovered by partial freezing with liquid nitrogen. In grain mounts, $\geq 200$ transparent heavy minerals for each sample were point-counted at suitable regular spacing to obtain real volume percentages ([87]) and grains of uncertain identification were systematically checked by Raman spectroscopy ([88]). In previous years, samples were analyzed by grain-counting of the 32-500 $\mu \mathrm{m}$ or 63-250 $\mu \mathrm{m}$ size classes. Transparent heavy-mineral assemblages, called for brevity "tHM-suites" throughout the text, are defined as the spectrum of extrabasinal detrital minerals - except carbonates and slow-settling phyllosilicates-denser than $2.90 \mathrm{~g} / \mathrm{cm}^{3}$ and identifiable under a transmitted-light microscope. According to the transparent-heavy-mineral concentration in the sample (tHMC), tHM suites are defined as very poor ( $\mathrm{tHMC}<0.5)$, poor $(0.5 \leq \mathrm{tHMC}<1)$, moderately poor $(1 \leq \mathrm{tHMC}<2)$, moderately rich $(2 \leq \mathrm{tHMC}<5)$, rich $(5 \leq \mathrm{tHMC}<10)$, very rich $(10 \leq \mathrm{tHMC}<20)$, or extremely rich $(20 \leq \mathrm{tHMC}<50)([89,90])$. The ZTR index, expressing the "chemical durability" of the tHM suite ([91]), is the sum of zircon, tourmaline, and rutile over total transparent heavy minerals ([92]). Significant minerals are listed in order of abundance (high to low) throughout the text. 
Table 1. Key petrographic, heavy-mineral, and geochemical parameters. $G S Z=$ median grain size; $Q=$ quartz; $F=$ feldspar $(K=K$-feldspar, $P=$ plagioclase); $\mathrm{L}=$ lithic grains $(\mathrm{Lm}=$ metamorphic: $\mathrm{Lmb}=$ metabasite, $\mathrm{Lmv}=$ low-rank metavolcanic; $\mathrm{Ls}=$ sedimentary: $\mathrm{Lc}=\mathrm{carbonate}, \mathrm{Lh}=\mathrm{chert}, \mathrm{Lp}=$ pelite; $\mathrm{Lv}=\mathrm{volcanic}$; $\mathrm{Lu}=$ ultramafic). $\mathrm{HM}=$ heavy-minerals; $\mathrm{tHMC}=$ transparent heavy-mineral concentration; $\mathrm{ZTR}=$ zircon + tourmaline + rutile; Ttn = titanite; Ap = apatite; Amp = amphibole; Px = pyroxene; Ep = epidote; Grt = garnet; CSKA = chloritoid + staurolite + andalusite + kyanite + sillimanite; and tHM = other transparent heavy minerals (anatase, brookite, monazite, olivine, Cr-spinel). Chemical indices explained in Section 3.3.

\begin{tabular}{|c|c|c|c|c|c|c|c|c|c|c|c|c|c|c|c|c|c|c|c|c|c|c|c|c|c|c|c|c|}
\hline Sample & GSZ & $\mathrm{Q}$ & $F$ & L & $\mathrm{P} / \mathrm{F}$ & Lm & Lv & Ls & mica & tHMC & ZTR & Ttn & Ap & Amp & $P x$ & Ep & Grt & CSKA & \&tHM & $\mathbf{A l} / \mathbf{S i}$ & $\mathrm{Zr}$ & CIA & CIX & WIP & $\overline{\alpha^{\mathrm{Al}} \mathrm{Ca}}$ & $\alpha^{\mathrm{Ti}} \mathrm{Ca}$ & $\overline{\alpha^{\mathrm{Al}} \mathrm{Na}}$ & $\alpha^{\alpha^{S m} \mathrm{Na}}$ \\
\hline PADMA & $\mu \mathrm{m}$ & & & & & & & & & & & & & & & & & & & & & & & & & & & \\
\hline S 3562 & 164 & 66 & 22 & 12 & $53 \%$ & 66 & 22 & 12 & $4 \%$ & 23 & 1 & 3 & 2 & 50 & 4 & 25 & 12 & 2 & 0 & 0.17 & 309 & 50 & 70 & 44 & 0.8 & 1.5 & 1.4 & 5.3 \\
\hline BR 820 & 130 & 67 & 17 & 15 & $51 \%$ & 37 & 12 & 51 & $9 \%$ & 12 & 3 & 2 & 1 & 37 & 5 & 34 & 13 & 3 & 1 & 0.18 & 2000 & 45 & 74 & 42 & 0.5 & 2.3 & 1.8 & 22.0 \\
\hline \multicolumn{29}{|c|}{ ESTUARY } \\
\hline BR 219 & 140 & 71 & 20 & 9 & $52 \%$ & 60 & 13 & 28 & $6 \%$ & 30 & 2 & 5 & 0 & 28 & 1 & 38 & 22 & 3 & 0 & 0.20 & 1345 & 47 & 75 & 43 & 0.5 & 2.6 & 1.9 & 17.9 \\
\hline BR 446 & 200 & 63 & 25 & 12 & $55 \%$ & 68 & 12 & 21 & $4 \%$ & 14 & 4 & 3 & 1 & 45 & 1 & 20 & 22 & 3 & 0 & 0.16 & 494 & 51 & 67 & 43 & 0.9 & 1.8 & 1.3 & 4.4 \\
\hline BR 1051 & 240 & 61 & 27 & 13 & $53 \%$ & 63 & 11 & 26 & $8 \%$ & 7 & 1 & 2 & 1 & 55 & 0 & 18 & 16 & 6 & 0 & 0.15 & 411 & 52 & 65 & 43 & 1.1 & 1.6 & 1.2 & 3.4 \\
\hline BR 8230 & 190 & 68 & 23 & 9 & $54 \%$ & 70 & 12 & 18 & $2 \%$ & 20 & 4 & 3 & 0 & 49 & 3 & 24 & 16 & 3 & 0 & 0.17 & 626 & 49 & 69 & 44 & 0.7 & 1.8 & 1.4 & 7.1 \\
\hline \multicolumn{29}{|l|}{ DELTA } \\
\hline S 3623 & 230 & 71 & 19 & 11 & $31 \%$ & 32 & 17 & 52 & $12 \%$ & 3 & 9 & 4 & 2 & 26 & 9 & 26 & 16 & 5 & 4 & n.d. & n.d. & n.d. & n.d. & n.d. & n.d. & n.d. & n.d. & n.d. \\
\hline BR 435 & 60 & 77 & 10 & 13 & $37 \%$ & 32 & 0 & 68 & $23 \%$ & 3 & 7 & 5 & 1 & 28 & 4 & 32 & 13 & 4 & 4 & 0.23 & 364 & 55 & 70 & 50 & 1.1 & 1.6 & 2.1 & 4.4 \\
\hline BR 809 & 140 & 72 & 16 & 12 & $43 \%$ & 50 & 9 & 41 & $5 \%$ & 13 & 7 & 4 & 1 & 28 & 4 & 18 & 31 & 8 & 1 & 0.13 & 1344 & 50 & 70 & 34 & 0.7 & 2.3 & 1.5 & 14.4 \\
\hline \multicolumn{29}{|l|}{ SHELF } \\
\hline SO 307 & 180 & 64 & 24 & 12 & $52 \%$ & 69 & 4 & 27 & $10 \%$ & 12 & 3 & 2 & 1 & 49 & 1 & 30 & 9 & 4 & 0 & 0.16 & 458 & 53 & 66 & 44 & 1.1 & 1.8 & 1.3 & 4.2 \\
\hline SO 316 & 65 & 72 & 21 & 8 & $47 \%$ & 60 & 3 & 38 & $16 \%$ & 8 & 5 & 2 & 2 & 50 & 3 & 26 & 9 & 2 & 0 & 0.17 & 361 & 53 & 66 & 46 & 1.1 & 1.7 & 1.4 & 3.4 \\
\hline SO 305 & 50 & 72 & 18 & 10 & $46 \%$ & 42 & 5 & 53 & $38 \%$ & 5 & 3 & 4 & 0 & 53 & 4 & 31 & 3 & 1 & 0 & 0.23 & 147 & 60 & 69 & 51 & 1.9 & 2.6 & 1.8 & $\begin{array}{l}2.4 \\
2.3\end{array}$ \\
\hline SO 105 & 55 & 72 & 7 & 22 & $47 \%$ & 34 & 4 & 62 & $8 \%$ & 2 & 2 & 2 & 0 & 64 & 2 & 26 & 2 & 2 & 0 & n.d. & n.d. & n.d. & n.d. & n.d. & n.d. & n.d. & n.d. & n.d. \\
\hline SO 347 & 80 & 72 & 18 & 10 & $58 \%$ & 46 & 11 & 43 & $10 \%$ & 4 & 18 & 0 & 0 & 28 & 0 & 38 & 8 & 6 & 0 & 0.11 & 581 & 38 & 66 & 38 & 0.4 & 1.0 & 1.4 & 5.2 \\
\hline
\end{tabular}




\subsection{Geochemistry}

Bulk-sediment chemical analyses were carried out at Service d'Analyse des Roches et des Minéraux (SARM-CRPG, Nancy, France). Sediment samples were first powdered in an agate mortar. Element concentrations were measured by inductively-coupled-plasma optical emission spectrometry (ICP-OES) and mass spectrometry (ICP-MS) on bulk aliquots of $\sim 100 \mathrm{mg}$ of sediment after lithium metaborate fusion $([93,94])$. The relative uncertainty for major element concentration is $<5 \%$, except for $\mathrm{Si}, \mathrm{Al}$, and Fe for which it is $\sim 2 \%$ (Table S5). For full information on analytical procedures and geostandards used see [94]. Grain-size subclasses split by sieving at $0.50 \phi$ were previously analyzed at ACME Laboratories Vancouver after lithium metaborate/tetraborate fusion and nitric acid digestion; major oxides and several minor elements were determined by ICP-ES, and trace elements by ICP-MS ([12]).

The Chemical Index of Alteration $\left(\mathrm{CIA}=100 \mathrm{Al}_{2} \mathrm{O}_{3} /\left(\mathrm{A}_{2} \mathrm{O}_{3}+\mathrm{CaO}-3.33 \mathrm{P}_{2} \mathrm{O}_{5}+\mathrm{Na}_{2} \mathrm{O}+\mathrm{K}_{2} \mathrm{O}\right) ;\right.$; 95$\left.]\right)$ and the Weathering Index $\left(\mathrm{WIP}=100 \cdot\left(\left(\mathrm{CaO}-3.33 \mathrm{P}_{2} \mathrm{O}_{5}\right) / 0.7+2 \mathrm{Na}_{2} \mathrm{O} / 0.35+2 \mathrm{~K}_{2} \mathrm{O} / 0.25+\mathrm{MgO} / 0.9\right) ;[96]\right)$ were calculated using molecular proportions of mobile alkali and alkaline earth metals corrected for $\mathrm{CaO}$ in apatite. Because correcting the CIA for $\mathrm{CaO}$ hosted in carbonates based on mineralogical data may result in significant error, a simplification of the CIA that does not consider $\mathrm{CaO}$ (CIX = $100 \mathrm{~A}_{2} \mathrm{O}_{3} /\left(\mathrm{A}_{2} \mathrm{O}_{3}+\mathrm{Na}_{2} \mathrm{O}+\mathrm{K}_{2} \mathrm{O}\right) ;[$ [97-100]) was also calculated. Enrichment or depletion of each single mobile element was evaluated by comparing its concentration to that of a non-mobile element of close magmatic compatibility (e.g., $\left.\alpha \mathrm{Ca}=[\mathrm{Ti} / \mathrm{Ca}]_{\text {sed }} /[\mathrm{Ti} / \mathrm{Ca}]_{\mathrm{UCC}}, \alpha \mathrm{Na}=[\mathrm{Sm} / \mathrm{Na}]_{\text {sed }} /[\mathrm{Sm} / \mathrm{Na}]_{\mathrm{UCC}} ;[101]\right)$ and to non-mobile $\mathrm{Al}\left(\alpha^{\mathrm{Al}} \mathrm{E}=[\mathrm{Al} / \mathrm{E}]_{\text {sed }} /[\mathrm{Al} / \mathrm{E}]_{\mathrm{UCC}} ;[98,99]\right)$ in our samples and in the Upper Continental Crust standard (UCC; $[102,103])$. The comparison among these different chemical indices allowed us to assess how they differently respond to controls other than weathering, including source-rock mineralogy, hydraulic sorting, grain size, and quartz addition ([104]).

\section{Results}

In this section, we illustrate the petrographic, heavy-mineral, and geochemical data newly obtained on Meghna estuary and Bengal shelf sands.

\subsection{Petrography and Heavy Minerals in Meghna Estuary Sand}

Samples BR446, BR8230, and BR1051 (Figure 2A-C) are upper-fine-grained (2.5-2.0 $\phi)$ litho-feldspatho-quartzose sands, with plagioclase $\geq$ K-feldspar and mostly medium-to-high rank metamorphic rock fragments (MI* 254-309). Micas are common (biotite/muscovite up to 3.5). The tHM suites are rich to very rich and dominated by calcic amphibole, epidote, and garnet-the classic "triad" diagnostic of orogenic Himalayan provenance [105]. Other minerals are minor and include titanite, prismatic and fibrolitic sillimanite, schorlitic and dravitic tourmaline, diopsidic clinopyroxene, staurolite, zircon, apatite, kyanite, rutile, and rare hypersthene and andalusite (Table 1). 


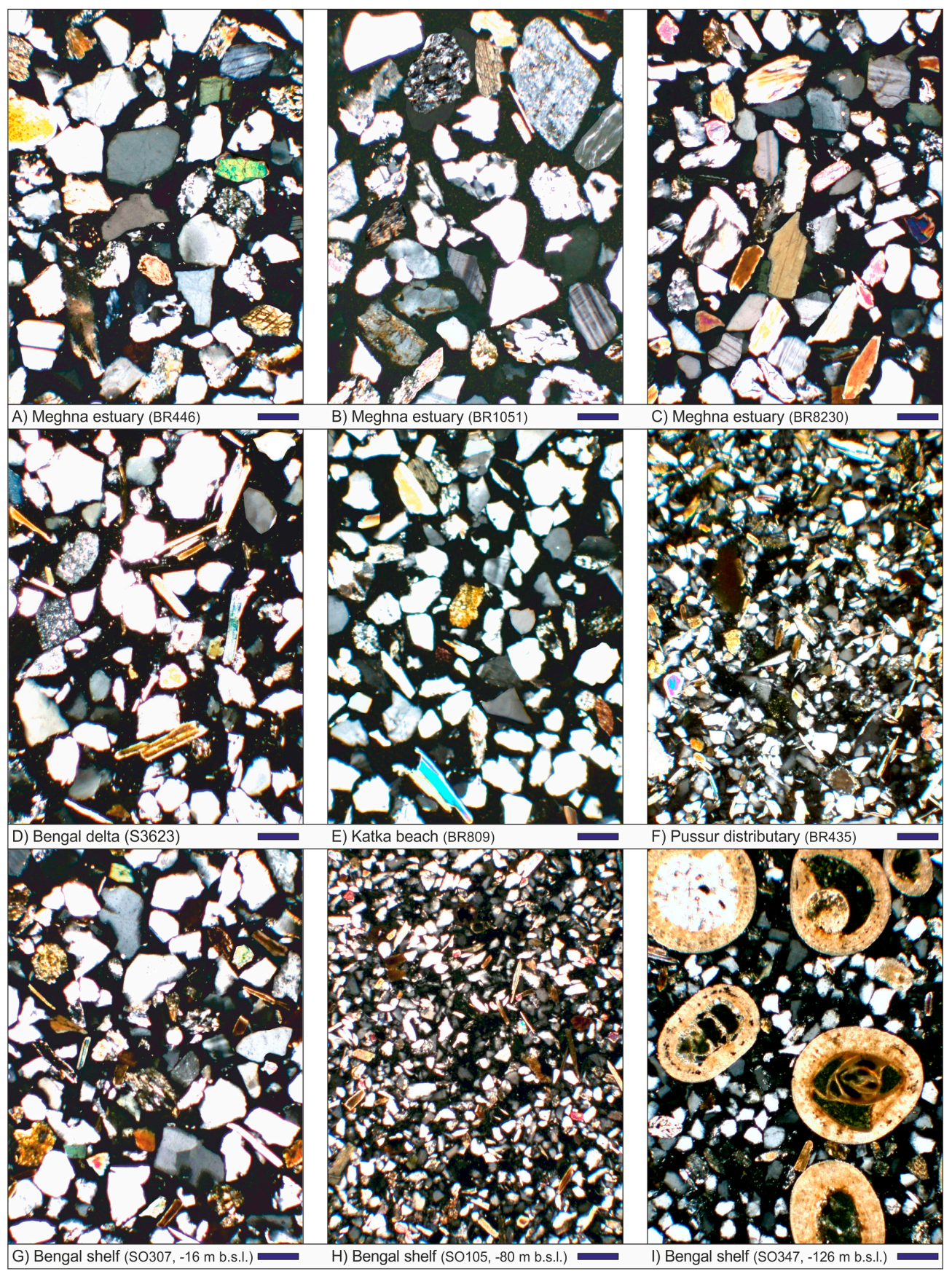

Figure 2. Petrography of litho-feldspatho-quartzose to feldspatho-quartzose sediments of the Meghna estuary, subaerial Bengal delta, and Bengal shelf. (A-C) Upper fine sands of the Meghna estuary. (D-F) Fine sand to silty sand of the Sundarbans. (G) Fine-grained micaceous sand in topsets of the subaqueous delta. (H) Mica-rich sandy silt in distal foresets of the subaqueous delta. (I) Very fine palimpsest sand in the outer-shelf; oversized ooids include benthic foraminifera with glaucony-filled chambers. All photos with crossed polars; all blue bars for scale are 100 microns.

\subsection{Petrography and Heavy Minerals in Bengal Shelf Sand}

The siliciclastic fraction of the studied samples cored in the subaqueous delta decreases seaward in grain size from fine sand on topsets (SO307; Figure 2G) to micaceous silty sand (SO316) and very coarse silt in upper foresets (SO105; Figure 2H), whereas it may be associated with ooids and bioclasts up to $300 \mu \mathrm{m}$ in diameter in the outer shelf (SO347; Figure 2I). Bioclasts, commonly occurring at the core of ooids, include mostly foraminifera (miliolids and rotaliids with less common textularids, 
bolivinids, and rare globigerinids) and fragments of gastropods or echinoids ([19]). The chambers of foraminiferal tests are commonly filled with glaucony.

Sand is litho-feldspatho-quartzose to feldspatho-quartzose (Figure 3A) with plagioclase $\geq$ K-feldspar and mostly medium-rank metasedimentary rock fragments (MI* 182-264). Micas are common (biotite/muscovite 2.7). In samples SO307 and SO316, rich to very rich tHM suites include amphibole, epidote, garnet, and minor diopsidic clinopyroxene, zircon, titanite, tourmaline, apatite, sillimanite, kyanite, staurolite, and chloritoid. Sample SO347 yielded a moderately poor suite notably richer in zircon and other durable minerals, with a markedly higher epidote/amphibole ratio ( 0.7 versus 1.7-2.0), more common chloritoid, and rarer titanite (Table 1).

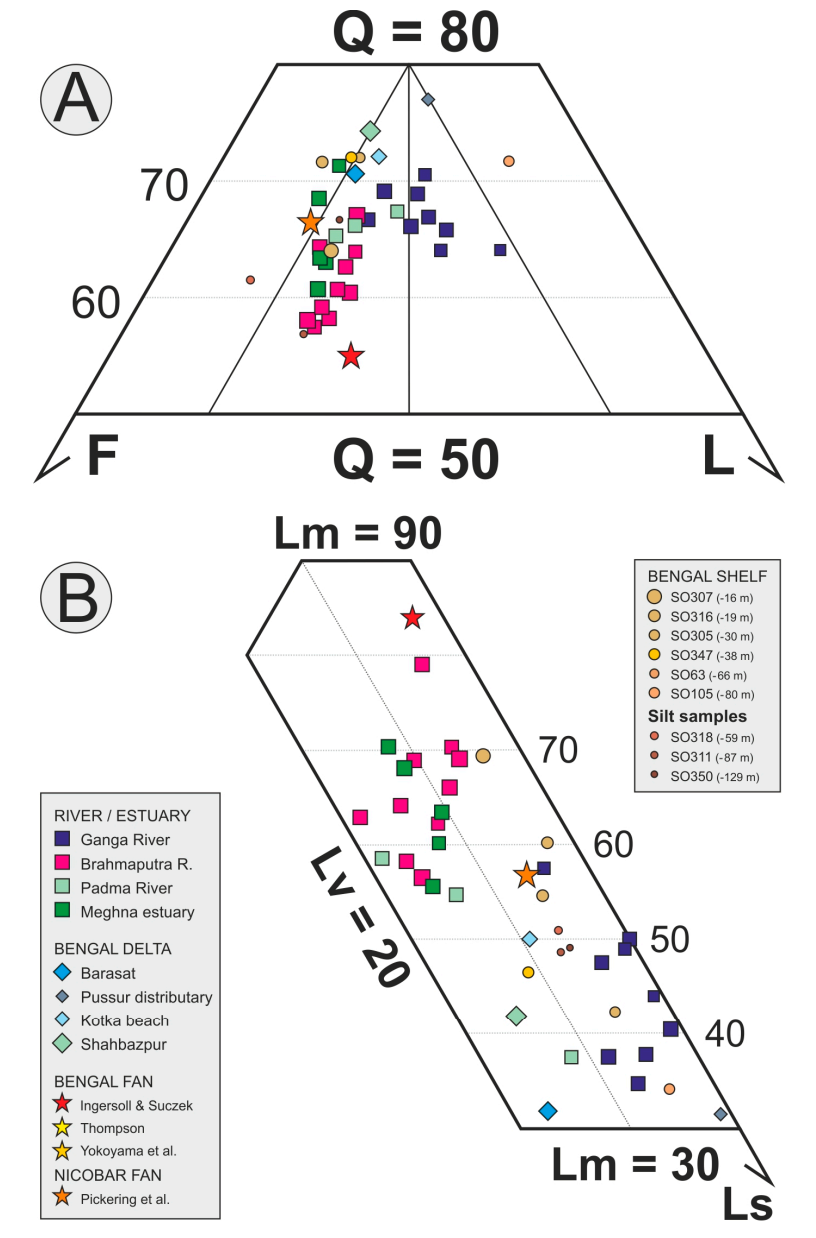

\section{$\mathbf{Q}=80$}
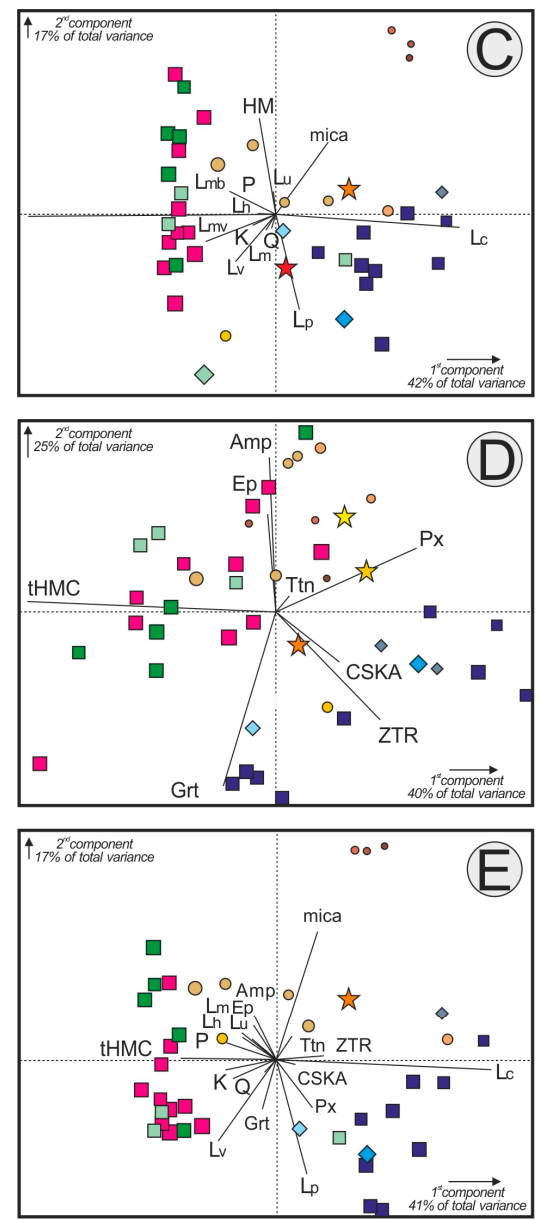

Figure 3. Petrography and heavy minerals in the Bengal sediment system (data for Ganga- Brahmaputra sand and Bengal shelf mud after [12,19]; data for Bengal-Nicobar Fan turbidites after [20-23]). Although detrital modes are controlled by several factors including seasonal and annual variability, hydraulic sorting, and grain size, litho-feldspatho-quartzose Brahmaputra sand is discriminated from mostly feldspatho-litho-quartzose Ganga sand in QFL (A) and LmLvLs (B) triangular diagrams, as well as in biplots ((C) petrography; (D) heavy minerals; (E) petrography and heavy minerals combined). Padma River and Meghna estuary sands range from almost pure Brahmaputra to mixed Ganga-Brahmaputra, whereas sediments of the subaerial delta are akin to the Ganga in the west and to the Brahmaputra in the east. Bengal shelf and fan sediments are either intermediate or close to the Brahmaputra. See Section 3 for an explanation of the biplot (drawn using CoDaPack software by [106]). Petrographic and mineralogical parameters are as in Table 1. 


\subsection{Geochemistry of Meghna Estuary and Bengal Shelf Sand}

The estuary and shelf sands have quite similar major element concentrations (mostly $\mathrm{SiO}_{2} 73-76 \%$; $\mathrm{Al}_{2} \mathrm{O}_{3} \sim 10 \%, \mathrm{Fe}_{2} \mathrm{O}_{3} 4.1-4.7 \%, \mathrm{MgO} 1.3-1.6 \%, \mathrm{CaO} 2.3-2.8 \%, \mathrm{Na}_{2} \mathrm{O} 1.7-1.8 \%, \mathrm{~K}_{2} \mathrm{O} 1.9-2.3 \%, \mathrm{TiO}_{2}$ $0.7-0.8 \%, \mathrm{P}_{2} \mathrm{O}_{5} \sim 0.2 \%$, MnO 0.07-0.11\%; Table S4 and [17]). Estuary sand tends to be richer in Ti, Y, REEs (rare earth elements), Th, $\mathrm{Nb}, \mathrm{Ta}, \mathrm{Cr}, \mathrm{Mn}, \mathrm{Cd}, \mathrm{Sn}$, and $\mathrm{Bi}$, reflecting concentration of ultra-dense minerals including garnet, monazite, and Fe-Cr-Ti oxides. Shelf sand, instead, displays higher $\mathrm{Cs}, \mathrm{Cu}$, As, and LOI; $\mathrm{K}$ and $\mathrm{Rb}$ also tend to be slightly higher, reflecting greater abundance of mica.

Among estuary sands, the coarsest-grained sample BR1051 is slightly enriched in Si and depleted in other major (Al, Fe, Mg, Ca, Ti, P) and minor elements (YREEs, Nb, Cr, Co, Ni). Conversely, sample BR8230 is depleted in Si and enriched in Fe, Mg, Ca, Ti, P, Mn, Sr, Ba, YREE, Th, U, Zr, Hf, V, Nb, Ta, $\mathrm{Cr}, \mathrm{Co}, \mathrm{Ni}, \mathrm{Zn}, \mathrm{Cd}, \mathrm{Sb}$, and $\mathrm{Bi}$, which is largely explained by the much higher concentration in heavy minerals and less quartz and feldspar (Table 1). Among shelf sands, sample SO347 is rich in ooids and bioclasts (Figure 2I), which explains its anomalously high $\mathrm{CaO}$ and $\mathrm{LOI}(4.4 \%$ and $4.9 \%$, respectively) and relatively high $\mathrm{Sr}$. Instead, $\mathrm{Al}, \mathrm{Fe}, \mathrm{Na}, \mathrm{K}, \mathrm{Rb}, \mathrm{Ba}$, and $\mathrm{Pb}$ are low.

\section{The Bengal Sediment System: Processes and Products}

In this section, we integrate our new mineralogical and geochemical data on the Meghna estuary and Bengal shelf sand and mud ([19]) with previously obtained data from the Ganga and Brahmaputra rivers and Bengal delta $([8,9,11-15,17,107,108])$. We also illustrate the strong variability of sediment composition observed in various parts of the Bengal sediment system and discuss specifically the control exerted by grain size and diverse hydrodynamic processes. These include suspension sorting (i.e., the partitioning of detrital grains at different depths in the water column according to their settling velocity, which depends in turn on their size, density, and shape; $[109,110])$ and selective entrainment (i.e., the preferential removal of lower density and, therefore, coarser settling-equivalent grains from deposits undergoing strong localized erosion; [111,112]).

As shown by previous studies, geochemical parameters may not be particularly helpful to discriminate sediment sources in provenance analysis ([113]), especially because of superposed grain-size and hydraulic-sorting control $([84,114])$. This is particularly true for the Ganga-Brahmaputra sediment system, where powerful tractive currents locally promote a full order-of-magnitude increase in the concentration of dense minerals relative to "neutral" composition (i.e., the composition that sediment would ideally have everywhere in the absence of hydrodynamic control).

If, on the one hand, bulk-sediment chemical composition offers little help for provenance discrimination, on the other hand it provides essential information to identify and quantify hydraulic-sorting effects by the precise assessment of elements such as REE, Th, Zr, or Hf. These elements do not enter the crystal lattice of common silicates and are thus progressively concentrated in residual melts until the latest stages of magmatic crystallization, when they form ultra-dense accessory phases such as monazite or zircon. Chemical data also allow us to highlight the differences in weathering conditions found in different parts of the Bengal sediment system.

\subsection{Ganga and Brahmaputra Rivers}

Ganga and Brahmaputra sands transported from the central and eastern Himalaya to the Bengal Sea are feldspatho-litho-quartzose to litho-feldspatho-quartzose metamorphiclastic, with subequal amounts of K-feldspar and plagioclase, low-to-high rank metamorphic lithic grains, biotite, muscovite, amphibole, epidote, and garnet (Figure 3). This is the typical fingerprint of orogenic detritus produced by focused erosion of deeply exhumed neometamorphic axial belts at the core of high-relief collision orogens (Axial Belt Provenance; [115]). 
Ganga sand is richer in quartz and contains limestone and dolostone grains from Himalayan sedimentary and metasedimentary rocks. Heavy minerals include common garnet, tourmaline, diopsidic clinopyroxene, kyanite, and sillimanite, documenting prominent contributions from amphibolite-facies metasedimentary rocks of the Greater Himalaya ([10]).

Brahmaputra sand is richer in feldspars (particularly plagioclase), lacks carbonate grains, and includes minor mafic and ultramafic detritus from ophiolitic units exposed along the Yarlung-Tidding suture zone. Heavy minerals are dominated by blue-green hornblende and epidote derived from amphibolite-facies Himalayan units exposed around the Namche-Barwa syntaxis as well as from Trans-Himalayan batholiths exposed in the Gangdese Range and Mishmi Hills. Hypersthene and chloritoid derived, respectively, from high-grade and low-grade rocks, also occur ([9]).

As it is the case for bedload sand, Ganga suspended load contains more quartz and significant calcite and dolomite, whereas Brahmaputra suspended load contains more Ca-plagioclase, very little dolomite, and no calcite. A moderately-rich epidote-amphibole-garnet tHM suite characterizes Ganga suspended load, whereas a rich amphibole-epidote suite characterizes Brahmaputra suspended load ([13]).

\section{Hydraulic Sorting}

Because of selective-entrainment effects, heavy-mineral concentration varies by one order of magnitude and more, from as low as 1.6 to 14.7 for Ganga bedload and from 3.0 to 22.6 for Brahmaputra bedload. Such a strong compositional variability is highlighted by geochemical data, showing that the concentration of zirconium, chiefly hosted in ultra-dense zircon grains, ranges from 116 to $\sim 1470 \mathrm{ppm}$ in Ganga sand and from 145 to 2750 ppm in Brahmaputra sand ([12,107]). Even garnet placers may form in Brahmaputra bedload, reaching a heavy-mineral concentration of 73.5, a grain density of $\sim 3.65 \mathrm{~g} / \mathrm{cm}^{3}$ (i.e., much higher than eclogite), and Th and $\mathrm{Zr}$ concentrations of $\sim 350 \mathrm{ppm}$ and $\sim 6500 \mathrm{ppm}$ (i.e., 33 times higher than the UCC standard; [12]).

Because of suspension sorting, quartz, feldspar, and heavy minerals steadily increase with depth in the river channel relative to slow-settling platy micas and clay. Among heavy minerals, fast-settling zircon and garnet tend to increase with channel depth relatively to less dense amphibole and epidote. Steady mineralogical trends are faithfully reflected by geochemical trends, with higher concentration in chemical elements preferentially hosted in micas or associated with clay and oxy-hydroxides (i.e., $\mathrm{Al}, \mathrm{K}$, $\mathrm{Rb}, \mathrm{Cs}, \mathrm{Ba}$, and heavy metals) close to the surface, and progressive increase in elements preferentially hosted in denser minerals (e.g., $\mathrm{Zr}, \mathrm{Hf}$ ) and more equant tectosilicates ( $\mathrm{Si}, \mathrm{Na}, \mathrm{Ca}$ ) toward the bed (Table 2).

\subsection{Meghna Estuary and Subaerial Bengal Delta}

Similar hydrodynamic processes characterize the Padma River and the Meghna estuary downstream, where fluvial and tidal currents locally cause strong erosion of river bars and redeposition in lower-energy estuarine tracts (Figure $6 \mathrm{~b}$ in [6]). In litho-feldspatho-quartzose sand, tHM suites range from rich to extremely rich and contain abundant amphibole, epidote, and common garnet (12-22\%; Table 1). Zr concentration varies from 218 to $2000 \mathrm{ppm}$, and also Y, REE, Th, Hf, Ta, Mn, and $\mathrm{P}$-all preferentially hosted in dense and ultra-dense minerals (monazite, zircon, rutile, garnet, allanite, apatite) — may be enriched by factors between three and nine (Figure 4A). In the shallow suspended load of the Meghna estuary, instead, the rich amphibole-epidote tHM suite contains $<3 \%$ garnet and only 163-169 Zr ppm. 
Table 2. Comparison among key mineralogical and geochemical parameters. Note the close similarity between tHM suites of Bengal shelf silt/sand and shallow and deep suspended load in the Brahmaputra River and Meghna estuary. In the subaerial delta, instead, tidal mud and sand have tHM suites closest to Ganga suspended load and bedload. Data sources cited in text; $n^{\circ}=$ number of samples; $\mathrm{C}=$ calcite; Do = dolomite. Chemical indices explained in Section 3.3. Other parameters are as in Table 1.

\begin{tabular}{|c|c|c|c|c|c|c|c|c|c|c|c|c|c|c|c|c|c|c|c|c|c|c|c|c|c|c|c|c|c|}
\hline Sample & $\mathbf{n}^{\circ}$ & $\mathrm{Q}$ & $\mathrm{K}$ & $\mathbf{P}$ & $\mathrm{Cc}$ & Do & mica & clay & $\mathbf{L}$ & HM & & tHMC & ZTR & Ttn & Ap & Amp & $P x$ & Ep & Grt & CSKA & \&tHM & & $\mathbf{A l} / \mathbf{S i}$ & $\mathrm{Zr}$ & CIA & CIX & WIP & $\alpha^{\mathrm{Al}} \mathrm{Ca}$ & $\alpha^{\mathrm{Al}} \mathrm{N}_{\mathrm{z}}$ \\
\hline GANGA RIVER & & & & & & & & & & & & & & & & & & & & & & & $\mathrm{mol}$ & & & & & & \\
\hline Shallow susp. load & 4 & 27 & 2 & 6 & 1 & 2 & 33 & 26 & - & 3 & 100.0 & 3 & 11 & 3 & 3 & 22 & 5 & 36 & 9 & 5 & 6 & 100.0 & 0.38 & 167 & 75 & 76 & 46 & 1.5 & 4.2 \\
\hline Deep susp. load & 4 & 48 & 6 & 10 & 3 & 3 & 17 & 10 & - & 3 & 100.0 & 3 & 10 & 4 & 2 & 28 & 6 & 28 & 13 & 5 & 4 & 100.0 & 0.22 & 228 & 64 & 70 & 41 & 0.9 & 2.4 \\
\hline Bedload sand & 8 & 57 & 7 & 7 & 3 & 2 & 9 & - & 10 & 6 & 100.0 & 8 & 8 & 4 & 2 & 28 & 6 & 17 & 28 & 7 & 1 & 100.0 & 0.15 & 445 & 58 & 68 & 34 & 0.6 & 1.7 \\
\hline \multicolumn{30}{|c|}{ BRAHMAPUTRA RIVER } \\
\hline Shallow susp. load & 4 & 35 & 4 & 10 & 0.1 & 0.6 & 36 & 9 & - & 5 & 100.0 & 4 & 3 & 3 & 1 & 45 & 4 & 36 & 5 & 2 & 2 & 100.0 & 0.32 & 186 & 64 & 73 & 54 & 2.2 & 2.4 \\
\hline Deep susp.load & 2 & 39 & 7 & 19 & 0 & 0.4 & 23 & 5 & - & 7 & 100.0 & 7 & 4 & 4 & 2 & 46 & 5 & 31 & 4 & 3 & 2 & 100.0 & 0.23 & 253 & 59 & 68 & 51 & 1.6 & 1.7 \\
\hline Bedload sand & 6 & 51 & 10 & 12 & 0 & 0 & 6 & 0 & 10 & 11 & 100.0 & 12 & 2 & 3 & 1 & 45 & 4 & 26 & 14 & 3 & 1 & 100.0 & 0.18 & 328 & 53 & 66 & 45 & 1.3 & 1.3 \\
\hline \multicolumn{30}{|c|}{ PADMA/MEGHNA ESTUARY } \\
\hline Shallow susp.load & 1 & - & - & - & - & - & - & - & - & - & & 6 & 1 & 3 & 1 & 50 & 5 & 34 & 3 & 3 & 0 & 100.0 & 0.34 & 164 & 66 & 74 & 53 & 2.4 & 2.8 \\
\hline Bedload sand & 6 & 53 & 9 & 10 & 0.5 & 0.2 & 5 & - & 8 & 14 & 100.0 & 14 & 3 & 3 & 1 & 50 & 1 & 21 & 18 & 4 & 0 & 100.0 & 0.16 & 453 & 51 & 67 & 43 & 0.9 & 1.3 \\
\hline \multicolumn{30}{|l|}{ BENGAL DELTA } \\
\hline Very coarse silt & 2 & 56 & 4 & 3 & 3 & 0.6 & 23 & - & 5 & 4 & 100.0 & 3 & 8 & 5 & 2 & 29 & 6 & 28 & 13 & 6 & 4 & 100.0 & 0.27 & 307 & 59 & 72 & 51 & 1.5 & 2.6 \\
\hline Sand & 3 & 63 & 9 & 6 & 0.3 & 0.5 & 7 & - & 9 & 5 & 100.0 & 8 & 8 & 4 & 1 & 27 & 7 & 22 & 23 & 6 & 2 & 100.0 & 0.13 & - & 50 & 70 & 34 & 0.7 & 1.5 \\
\hline \multicolumn{30}{|l|}{ BENGAL SHELF } \\
\hline Fine silt & 3 & 24 & 3 & 8 & 0.9 & 0.9 & 30 & 25 & 2 & 6 & 100.0 & 5 & 5 & 4 & 2 & 51 & 2 & 28 & 4 & 4 & 1 & 100.0 & 0.36 & 129 & 71 & 76 & 50 & 4.6 & 3.7 \\
\hline Very coarse silt & 2 & 49 & 5 & 3 & 2 & 2 & 23 & - & 7 & 8 & 100.0 & 4 & 3 & 3 & 1 & 58 & 3 & 29 & 3 & 2 & 0 & 100.0 & 0.23 & 147 & 60 & 69 & 51 & 1.9 & 1.8 \\
\hline Sand & 3 & 57 & 8 & 9 & 0 & 0 & 12 & - & 8 & 5 & 100.0 & 7 & 9 & 2 & 1 & 42 & 2 & 32 & 8 & 4 & 0 & 100.0 & 0.16 & 467 & 53 & 66 & 45 & 1.1 & 1.4 \\
\hline
\end{tabular}



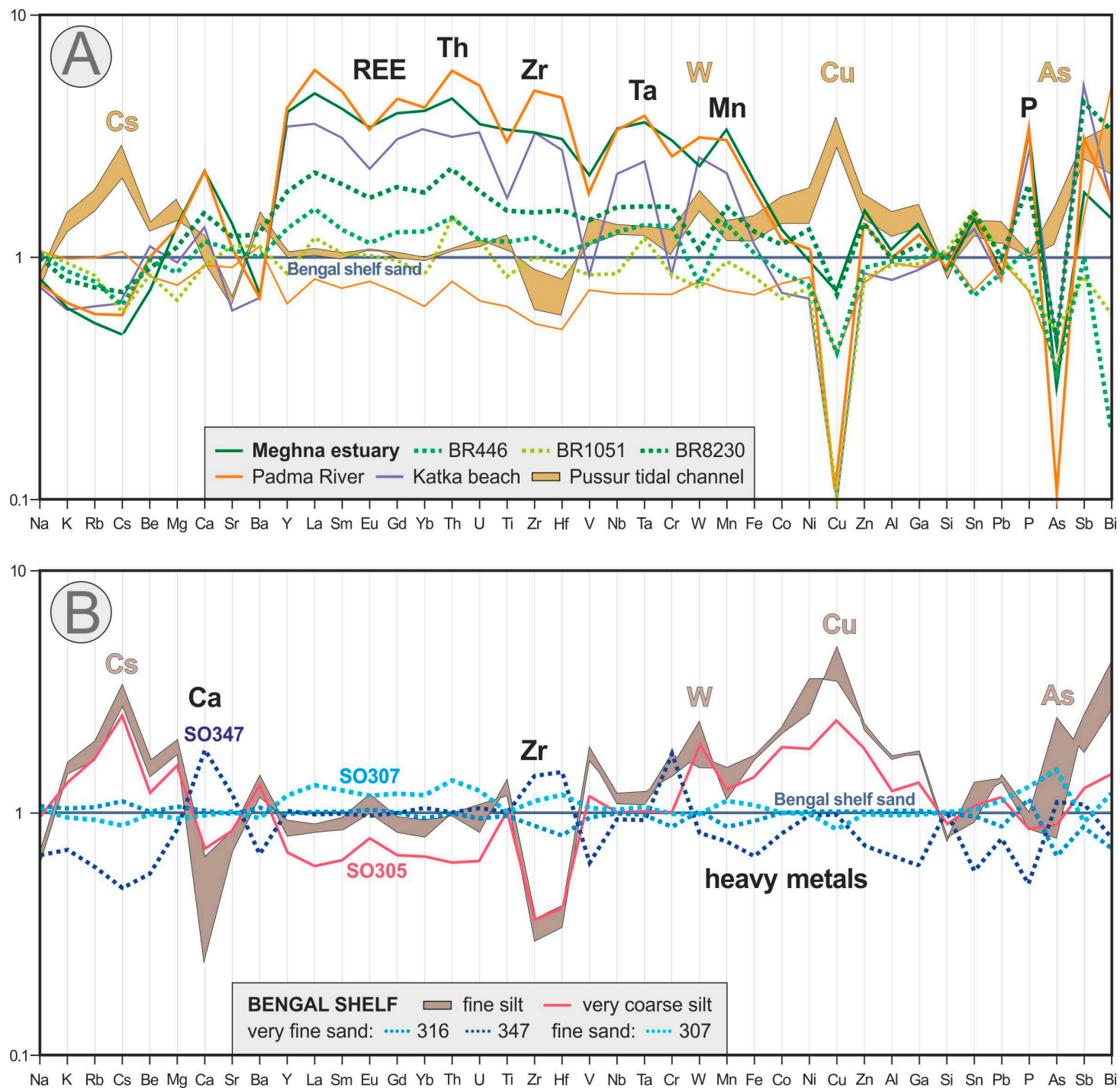

Figure 4. Sedimentary geochemistry (elements arranged following the periodic table group by group; data normalized to the median composition of shelf sand samples SO307, SO316, and SO347; Table S4). (A) Fluvial, estuary, and subaerial delta sediments compared to Bengal shelf sand. The Katka beach and some Padma and Meghna estuary samples are markedly enriched in elements preferentially hosted in heavy minerals (e.g., Y, REE, Th, Zr, Ta, Mn, and P), indicating that they are semi-placer lags generated by selective entrainment of lower density grains. Shelf sand has more Cs, W, Cu, and As than fluvial and estuary sands, elements all markedly enriched in tidal mud of the Pussur distributary. (B) Bengal shelf mud compared to Bengal shelf sand. Geochemical signatures are chiefly controlled by grain size and clay content. Besides abundant $\mathrm{Ca}$ associated with allochems (Figure 2I), sample SO347 displays low concentration in heavy metals, relatively high $\mathrm{Zr}$, and low $\mathrm{Al}$, suggesting effective reworking and winnowing of palimpsest sand on the outer shelf.

Subaerial Bengal delta samples range from feldspatho-litho-quartzose to litho-feldspatho-quartzose and tend to be richer in quartz and much poorer in plagioclase than Meghna estuary sand. The tHM suites are only moderately rich, including $13-16 \%$ garnet, $<3 \%$ kyanite, and $\leq 0.5 \%$ staurolite; $\mathrm{Zr}$ is $<400 \mathrm{ppm}$. The Katka beach sand, instead, has a very rich tHM suite including $32 \%$ garnet, $4 \%$ kyanite, and $2.5 \%$ staurolite; $\mathrm{Zr}$ is $1344 \mathrm{ppm}$. This sample can thus be considered as a semi-placer lag formed by selective removal of low-density grains by storm waves during beach erosion. 


\subsection{Bengal Shelf}

The same mineralogical trend observed from bedload to deep and shallow suspended load in fluvial and estuary sediments is reproduced from sandy topsets to silty foresets and bottomsets on the subaqueous delta, with progressive enrichment in platy phyllosilicates in distal settings at the expense of tectosilicates and heavy minerals (Table 2). Among heavy minerals, slower-settling amphibole tends to increase in fine silt at the expense of fast-settling garnet, which is more common in sand. The notable enrichment in durable ZTR minerals, dearth of pyroxene, and the high epidote/amphibole ratio in sample SO347 hint at early diagenetic dissolution of palimpsest sediment originally deposited by the Ganga River.

The analyzed Bengal shelf sands display Zr concentrations between 361 and 581 ppm, higher than the UCC values by factors between approximately two and three but not as high as the Padma River, Meghna estuary, and Katka beach semi-placers (Zr 1344-2000; Table 1). This reflects prevailing depositional processes on the subaqueous delta and only mild concentration of fast-settling heavy minerals by winnowing of slow-settling grains such as phyllosilicates rather than by strong erosional processes.

The joint inspection of Figure 4A,B reveals another aspect of hydraulic control on the compositional variability of Bengal Shelf sediments associated with either selective winnowing or settling of clay. The analyzed shelf sands display higher concentrations than fluvial and estuarine bedload in heavy metals and elements such as Cs and As, largely adsorbed on clay or associated with oxy-hydroxides and organic matter (e.g., [116-118]). The concentration of these elements is even markedly higher in tidal muds of the Pussur distributary channel, and highest in fine silt of distal foresets and bottomsets of the subaqueous delta.

Besides abundant $\mathrm{Ca}$ associated with ooids and bioclasts (Figure 2I), the outer shelf sample SO347 displays the lowest concentration in heavy metals, relatively high $\mathrm{Zr}$, and low $\mathrm{Al}$ (Figure 4B), suggesting effective winnowing of clay by storm-generated bottom currents. Palimpsest sand including ooids and bioclasts represents drowned beach barriers deposited during the last lowstand stage around $20 \mathrm{ka}([119,120])$, followed by reworking and sediment starvation during the Holocene transgression, as also indicated by growth of glaucony within foraminiferal chambers and lack of reported sites where ooids are forming at present in the Indian Ocean ([121,122]). Protracted sediment starvation just in front of the largest deltaic sediment system on Earth indicates that throughout the Holocene sea-level rise sediment was systematically swept by tropical cyclones toward the Swatch of No Ground, and from there funneled toward the Bengal Fan ([7]), thus systematically bypassing the outer shelf.

\subsection{Chemical Weathering}

Besides physical effects such as selective mechanical breakdown, which can be considered as negligible for the purpose of this study $([123,124])$, and hydraulic-sorting, agents capable of compositional modification include chemical weathering. Previous studies have highlighted the difference between the essentially physical Brahmaputra River system — characterized by a cold and arid climate in Tibet, ultra-rapid erosion across the eastern Himalayan syntaxis, and very high runoff in the narrow floodplain - and the Ganga river system, where storage time in the floodplain is longer and weathering notably more intense $([15,125])$. This is reflected by clay-mineral assemblages ([126-130]), which are dominated by illite $(70-80 \%)$ with subequal amounts of chlorite and kaolinite $(\sim 10 \%$ each) and negligible smectite $(\leq 5 \%)$ in Brahmaputra suspended load, whereas smectite/montmorillonite is much more common (20-40\%) in Ganga suspended load.

The analysis presented here adds to the thorough study by [17], who used mobile to immobile element ratios including $\mathrm{K} / \mathrm{Si}$ and $\mathrm{H}_{2} \mathrm{O}^{+} / \mathrm{Si}$ as well as the abundance of detrital calcite to document an increase of chemical weathering in the Himalayan system since the Last Glacial Maximum. The use of diverse chemical indices allows us not only to clarify their different response to different controls (Table 1) but also to perceive the different qualitative character of weathering processes in the Brahmaputra and Ganga catchments (Table 2). 


\subsubsection{The Meaning of Chemical Indices}

The broadly homogeneous composition of Meghna estuary and Bengal shelf sediments reflects the continuous supply of enormous volumes of detritus dominantly derived from the Himalayan orogen via the Ganga and Brahmaputra rivers. Because, in this huge system, sediment provenance can be safely considered as substantially unvaried in the short term, modern sediment samples offer a way to test whether the so-called chemical indices of weathering are indeed mainly controlled by climate-related weathering, which at the very short time scale of a few years can be held as roughly invariant, or they are largely or even overwhelmingly controlled by diverse factors including source-rock lithologies, hydraulic sorting, quartz addition, and grain size. Such a critical assessment is needed to prevent that these indices are used indiscriminately as an act of faith.

Close inspection of Table 1 is instructive in this regard. $\mathrm{Al} / \mathrm{Si}$, a widely used proxy for grain size (e.g., [8]), correlates quite well with the WIP $(r=0.83$; significance level $=0.1 \%)$, which confirms that the WIP is strongly dependent on grain size and quartz content and, therefore, can hardly be used as a measure of weathering in sediments $([98,99,131])$. The CIA also correlates with $\mathrm{Al} / \mathrm{Si}$ (i.e., with grain size; $r=0.64)$ and best with $\alpha^{\mathrm{Al}} \mathrm{Ca}(r=0.89)$, a correlation that disappears if the CIX is calculated instead. The addition of carbonate grains, also formed as allochems within the sedimentary basin (e.g., Figure 2I), may lead to the underestimation of weathering, even markedly if not properly identified and corrected for.

An almost perfect correlation exists between $\alpha^{\mathrm{Sm}} \mathrm{Na}$ and $\mathrm{Zr}(r=0.98$; significance level $=0.1 \%)$, which demonstrates the overwhelming effect of concomitant hydraulic concentration of ultra-dense minerals such as REE-rich monazite and zircon. Dominant hydraulic-sorting control on trace-element concentration confirms that $\alpha$ indices using as a reference non-mobile elements such as $\mathrm{Ti}, \mathrm{Sm}, \mathrm{Nd}$ or Th ([101]), which are preferentially hosted in ultra-dense minerals (e.g., monazite, allanite, ilmenite, rutile), cannot be used to evaluate weathering in sediments deposited by tractive currents $([98,99])$. The hydraulic-sorting effect is efficiently sterilized by using, instead, the non-mobile element $\mathrm{Al}$ as a reference (Table 1).

The study of African sediments has shown that $\alpha^{\mathrm{Al}} \mathrm{Na}$ is the chemical index most sensitive to weathering, largely because of the high emigration rate of $\mathrm{Na}^{+}$from plagioclase under active leaching ([132-135]). The use of $\alpha^{\mathrm{Al}} \mathrm{Na}$-and in general of $\alpha^{\mathrm{Al}} \mathrm{E}$ indices instead of $\alpha^{\mathrm{Sm}} \mathrm{Na}, \alpha^{\mathrm{Ti}} \mathrm{Ca}$, $\alpha^{\mathrm{Th}} \mathrm{K}, \alpha^{\mathrm{Nd}} \mathrm{Sr}$, and $\alpha^{\mathrm{Th}} \mathrm{Ba}$ indices-avoids undesired perturbations up to even more than one order of magnitude associated with the locally strong hydraulic concentration or depletion of heavy minerals preferentially hosting Ti or REE (Table 1), and is thus recommended.

No chemical index, however, can be claimed to be a truthful proxy for weathering if taken alone. The use of the CIX instead of the CIA circumvents the problems associated with correction for $\mathrm{CaO}$ not hosted in silicates, although the CIX is more affected than the CIA by selective-entrainment processes and reaches extreme values even in the absence of weathering in placer deposits strongly depleted in low-density alkali feldspars. Being strongly affected by quartz addition, the WIP is best used in conjunction with the CIA or the CIX to evaluate the extent of recycling rather than the intensity of weathering $([98,131])$.

\subsubsection{Weathering Processes}

The inability of the WIP to measure weathering is clearly exposed by inspection of Table 2, which shows that all indices increase steadily with decreasing grain size from bedload to deep and shallow suspended load, being minimum in sand and maximum in clay in all tracts of the Bengal sediment system $([8,13,15,108])$. Higher values of the WIP, however, indicate lower and not higher weathering intensity. The reason why the WIP is unduly lower for sand than for clay is that the WIP is affected principally by quartz content-which is markedly higher in bedload sand than in phyllosilicate-rich suspended load-rather than by chemical weathering.

All indices but $\alpha^{\mathrm{Al} C}$ a concur to confirm more intense weathering in the Ganga catchment than in the Brahmaputra catchment. The main reasons why $\alpha^{\mathrm{Al}} \mathrm{Ca}$ and $\alpha^{\mathrm{Al}} \mathrm{Na}$ give opposite indications 
for the two rivers do not only reflect lithological differences in source terranes but also the distinct character of weathering in the two river systems. Carbonate rocks provide a much larger share of detritus to the Ganga River, largely via the Gandak tributary that drains Tethys Himalayan and Greater Himalayan carbonate and metacarbonate rocks in the upper course and some Lesser Himalayan metacarbonates in the middle course ([10]). The Gandak River is estimated to contribute possibly even as much as half of total Ganga load ([100]). Consequently, despite conspicuous chemical weathering in the floodplain, the $\mathrm{Ca} / \mathrm{Al}$ ratio is higher in Ganga bedload and deep suspended load than in the average upper continental crust. In Brahmaputra sediments, instead, $\alpha^{\mathrm{Al}} \mathrm{Ca}$ displays the same values and trend as $\alpha^{\mathrm{Al}} \mathrm{Na}$ from bedload to deep and shallow suspended load (Table 2) because in this case both elements are chiefly controlled by plagioclase weathering. The Brahmaputra River carries a significant amount of carbonate grains as far as the Himalayan mountain front $(\sim 6 \%, 20 \%$ of which calcite and $80 \%$ dolomite), reduced to $1 \%$ (100\% dolomite) within the first $100 \mathrm{~km}$ of transport across the foreland basin, and progressively reduced to zero farther downstream ([9]). On the same samples studied for mineralogy, manometrical measurement of $\mathrm{CO}_{2}$ after $3 \mathrm{~h}$ for calcite and 1 week for dolomite gave comparable results: $2.2 \%$ calcite and $2.2 \%$ dolomite at the mountain front, $0.2 \%$ calcite and $0.4 \%$ dolomite after $100 \mathrm{~km}$ of floodplain transport, and $0.003-0.2 \%$ calcite and $0.004-0.5 \%$ dolomite at the entry point in Bangladesh, where calcite is, however, still $0.15 \%$ and dolomite $1.2 \%$ in suspended load ([107). Near complete dissolution of carbonate grains in the Assam foreland-basin lowlands is a weathering effect ascribed to huge Brahmaputra discharge with high $p \mathrm{CO}_{2}$ levels in river waters undersaturated with respect to carbonates ([136,137]).

In the Meghna estuary, weathering indices are either similar to Brahmaputra sediments or intermediate between Brahmaputra and Ganga sediments. In the subaerial Bengal delta, tidal mud of the Pussur distributary results as weathered as Ganga-Brahmaputra suspended load. In the subaqueous delta, sediments are markedly depleted in $\mathrm{Ca}$ and $\mathrm{Na}$ as grain size decreases and clay-the product of chemical weathering - progressively increases from sandy topsets to muddy distal foresets and bottomsets.

\section{Provenance}

In this section, we draw inferences about provenance and sediment mixing along the routing system that includes the Meghna estuary and the Bengal shelf, and terminates in the Bengal-Nicobar Fan.

\subsection{Meghna Estuary}

The Ganga and Brahmaputra rivers drain different geological domains besides the Himalayan thrust belt and, thus, carry sediments with distinguishable mineralogical and isotopic fingerprints (Figure 3). Ganga sediments, largely derived from Greater and Lesser Himalayan rocks, are, for instance, characterized by more negative $\varepsilon_{\mathrm{Nd}}$ and higher ${ }^{87} \mathrm{Sr} /{ }^{86} \mathrm{Sr}$ than Brahmaputra sediments, which are partly derived from juvenile Trans-Himalayan magmatic rocks in south Tibet $([100,107])$. The relative supply from the two big rivers to the Padma River, the Meghna estuary, and the Bengal shelf is, however, difficult to calculate precisely because of the strong variability of sediment composition, largely caused by hydraulic-sorting effects.

In the Meghna estuary, detrital modes are closer to Brahmaputra sand than to Ganga sand (Figure 3), and tHM suites are virtually indistinguishable from Brahmaputra tHM suites (Table 2). The close similarity of tHM suites in the Brahmaputra, Padma River, and Meghna estuary (Figure 6) is, however, partly an effect of heavy-mineral concentration, which is $50 \%$ to $100 \%$ higher in Brahmaputra bedload and suspended load than in Ganga bedload and suspended load $([12,13])$. The same holds largely true also for Nd and Sr isotopic ratios, which in the Padma River, Meghna estuary, and Bengal shelf are virtually the same as in Brahmaputra sediments (Figures 7 and 8 in [17,55]). As highlighted in [138], most Nd and much Sr are hosted in heavy minerals, the abundance of which is markedly higher in Brahmaputra than in Ganga sediments, as discussed further in the following subsection. 
The mineralogical and geochemical signatures of suspended load are intermediate between the Ganga and Brahmaputra rivers, but notably closer to the Brahmaputra (e.g., relatively low quartz/feldspar ratio, heavy-mineral assemblages dominated by hornblende and epidote with minor garnet, diopside, sillimanite, and kyanite). A few carbonate grains occur in Padma bedload, and suspended load has more $\mathrm{CaO}$ than in the Brahmaputra river at any water depth but more so in shallow suspended load, suggesting that contributions from the Ganga River, although invariably subordinate, is more significant for finer-grained fractions (Figure 5). Greater Ganga contribution for cohesive mud fractions is also indicated by the anomalous increase in the Q/F ratio with decreasing grain size of Bengal shelf muds ([19]).
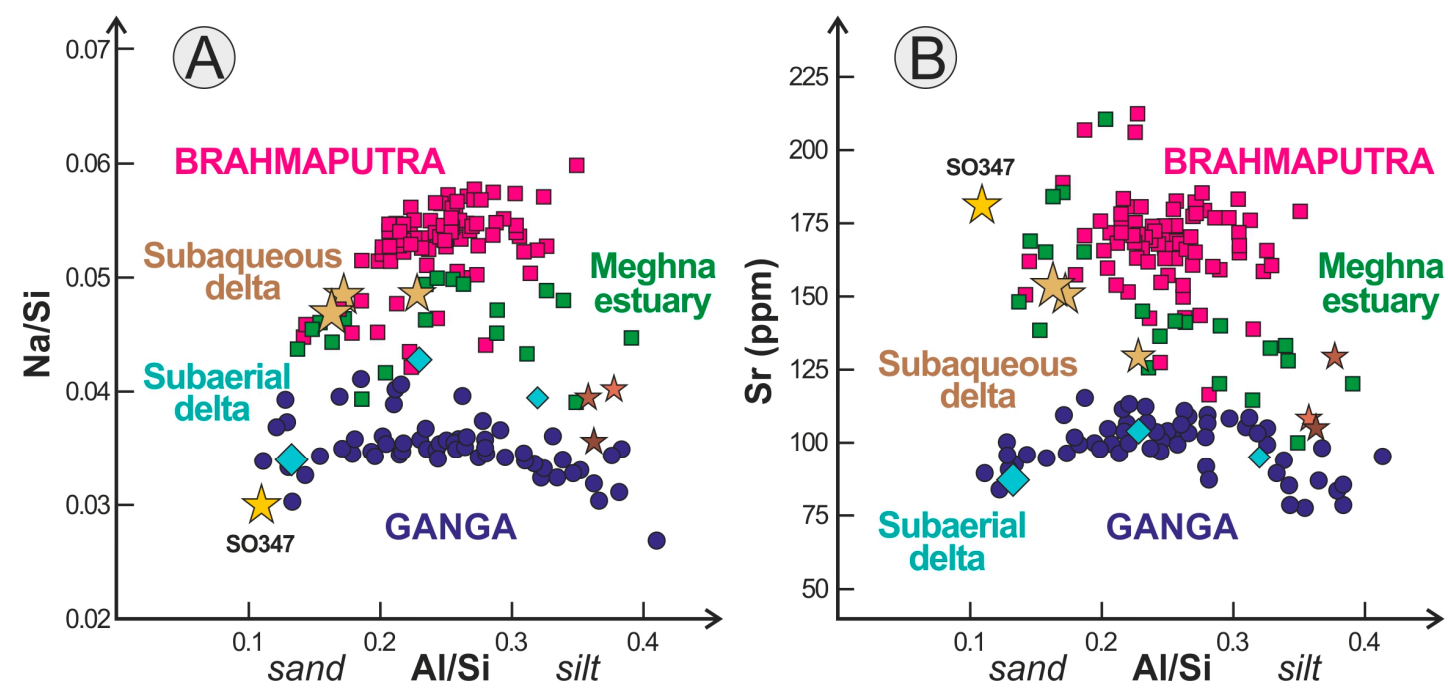

Figure 5. Geochemical discrimination between Ganga and Brahmaputra provenance. Brahmaputra sediments contain more plagioclase and epidote and, therefore, more $\mathrm{Na}$ (A) and $\mathrm{Sr}$ (B). Subaerial-delta sediments are akin to the Ganga, whereas subaqueous-delta sediments are akin to the Meghna estuary and to the Brahmaputra for sand but closer to the Ganga for fine silt. Sample SO347 is as low in Na as Ganga sand, Al poor because of the winnowing of clay, and $\mathrm{Sr}$ rich because of common calcareous ooids and bioclasts. The size of symbols is roughly proportional to the grain size for subaerial and subaqueous delta samples.

Forward mixing calculations based on integrated petrographic and heavy-mineral data $([139,140])$ indicate that sand supply from the Brahmaputra river is at least twice that of the Ganga River, despite the drainage basin of the Ganga being notably greater than that of the Brahmaputra. Similar calculations based on clay-mineral assemblages (as reported in Table 1 in [130]) indicate that the Ganga River contributes $\leq 40 \%$ and the Brahmaputra River $\sim 60 \%$ of clay minerals fed into the Bay of Bengal ([19]). Because the drainage area of the Brahmaputra is $\sim 60 \%$ that of the Ganga, such a broad agreement among estimates based on different compositional parameters and grain-size fractions would imply that average denudation rates are about three times higher in the Brahmaputra catchment than in the Ganga catchment. However, a larger part of the Ganga sediment flux is sequestered in the foreland basin and part of it is diverted southward before reaching the Brahmaputra confluence.

Tracing of Sr concentration throughout the Holocene succession of the Bengal delta indicates that the western part of the subaerial delta consists almost entirely of low-Sr Ganga sediments, whereas high-Sr Brahmaputra sediments have remained dominant in the eastern region including the modern estuary ([55]). This is consistent with petrographic and heavy-mineral modes of sand cored in the western part of the subaerial Bengal delta (Figure 2D) and collected at Katka beach (Figure 2E), which are closer to Ganga sand than to Brahmaputra sand (Figure 3), and with the tHM suite of tidal mud in the Pussur distributary (Figure 2F), which is indistinguishable from deep suspended load in the Ganga River (Figure 6). 


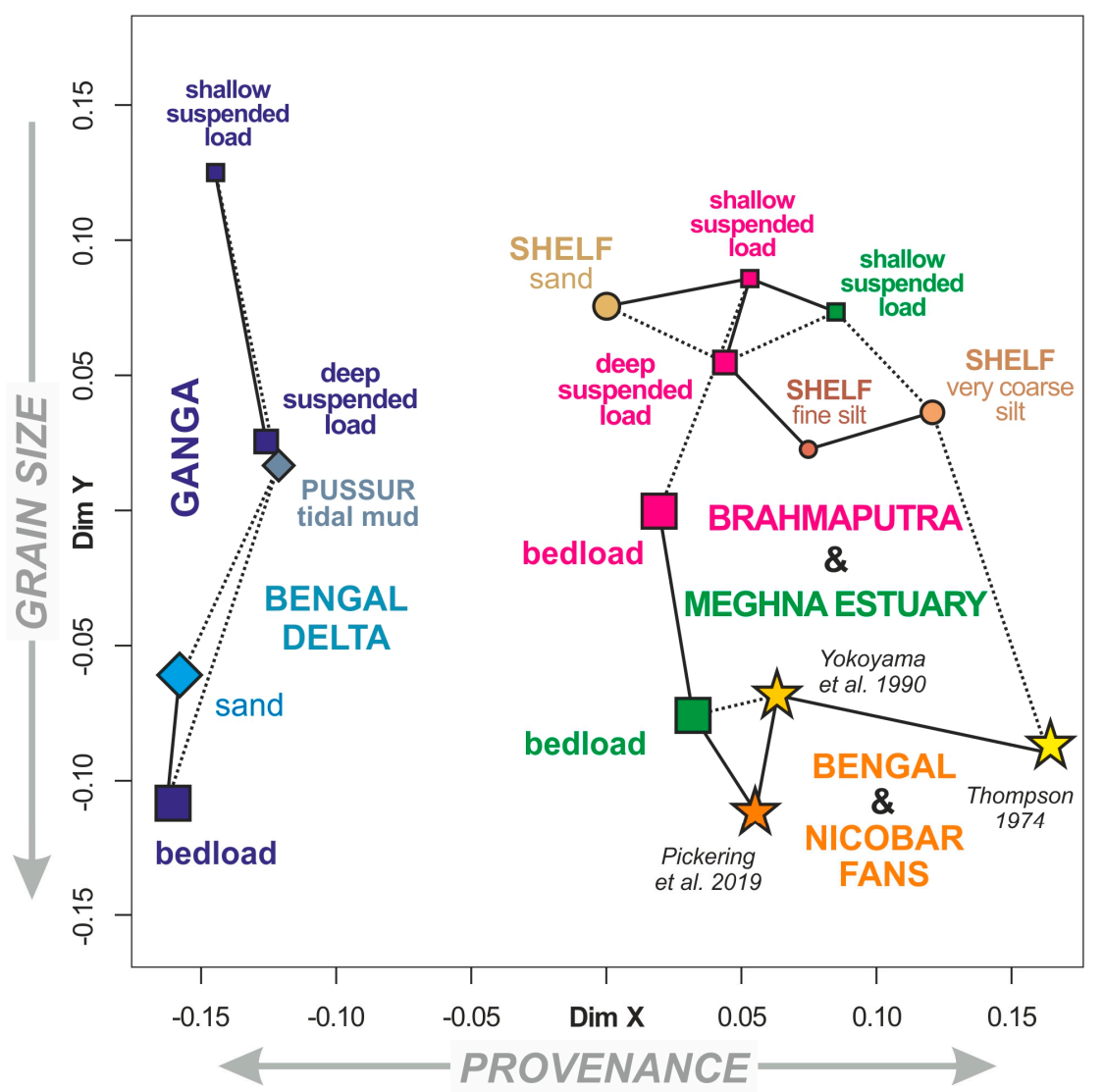

Figure 6. Multidimensional scaling map based on heavy-mineral data (plotted using the "provenance" package of [141]). The distance among samples is approximately proportional to the Kolmogorov-Smirnov dissimilarity of their tHM suites. Solid and dashed lines link closest and second-closest neighbors, respectively; the "stress" value of the configuration is 5.4, indicating a "good" fit ([78]). Samples are separated chiefly by grain size along the $y$-dimension and by provenance along the $x$-dimension, which highlights the Ganga affinity of subaerial Bengal delta sediments, and the Brahmaputra affinity of Meghna estuary, Bengal shelf, and Bengal Fan sediments. As in Figure 3D, Brahmaputra affinity of estuary, shelf, and fan sediments partly reflects the higher heavy-mineral concentration in Brahmaputra than in Ganga sediments.

Minerals Controlling the Sr and Nd Budgets

In shallow to deep suspended load, heavy minerals are estimated to contribute $17 \%$ to $21 \%$ of total Sr (13\% to 16\% from epidote) for the Ganga, and 25\% ( 20\% from epidote) for the Brahmaputra. Heavy minerals are estimated to contribute $53 \%$ to $76 \%$ of total $\mathrm{Nd}$ (43-46\% to $60-65 \%$ from allanite + monazite + titanite) in both Ganga and Brahmaputra shallow to deep suspended load. In bedload, heavy minerals may contribute up to $28 \%$ of total Sr ( $20 \%$ from epidote) and up to $96 \%$ of total $\mathrm{Nd}$ (88\% from allanite + monazite + titanite) for the Ganga, and even up to $84 \%$ of total Sr (66\% from epidote) and almost all of $\mathrm{Nd}(93 \%$ from allanite + monazite + titanite) for the Brahmaputra ([12,13]).

Most of the remaining $\mathrm{Sr}$ is hosted in Ca-plagioclase, which is at least twice as abundant in Brahmaputra than in Ganga bedload and suspended load, which explains why Brahmaputra sediments contain 50-60\% more Sr than Ganga sediments in any size fraction (Figure 5). In summary, the Sr and $\mathrm{Nd}$ budgets are chiefly dependent on Ca-plagioclase and heavy minerals (between 56\% and 70\% for the Ganga and between $70 \%$ and $96 \%$ for the Brahmaputra), which in any size fraction are more abundant in Brahmaputra than in Ganga sediments by factors between 1.5 and $\geq 2$ (Table 2). 


\subsection{Bengal Shelf Sediments}

The petrographic and chemical composition of shelf sand is broadly intermediate between Brahmaputra and Ganga bedload (Figure 5), indicating that both rivers contribute large amounts of sediment. Partly because of the reasons discussed above, the tHM suite of shelf sediments (Figure 6) and their $\mathrm{Sr}$ and $\mathrm{Nd}$ isotopic fingerprints (Figures 7 and 8 in [17]) are instead barely distinguishable from those of Brahmaputra and Meghna estuary sediments.

Silt deposited on the Bengal shelf has quartz/feldspar ratio and proportions among feldspar minerals very close to Brahmaputra silt, and a tHM suite virtually indistinguishable from suspended load in both the Brahmaputra River and Meghna estuary (Figure 6). Fine cohesive mud deposited on the distal foresets and bottomsets of the subaqueous delta may be interpreted as suspended load largely delivered by the Meghna estuary mixed with clay largely supplied by tidal distributaries draining the Sundarban swamps ([19]). Illite-dominated clay-mineral assemblages include subordinate chlorite, smectite, and kaolinite in very similar proportions as clay minerals in Meghna estuary mud ([19,130]).

These estimates confirm that sediment of all size fractions deposited on the subaqueous Bengal delta is mostly derived from the Meghna estuary-with possibly significant contributions of mud delivered by tidal distributaries draining the western part of the inactive subaerial delta-and ultimately supplied between $30 \%$ and $40 \%$ by the Ganga River and between $60 \%$ and $70 \%$ by the Brahmaputra River. Sediment flux across the Bay of Bengal and subsequently funneled via the Swatch of No Ground to the Bengal Fan is thus presently Brahmaputra-dominated (Figure 7).

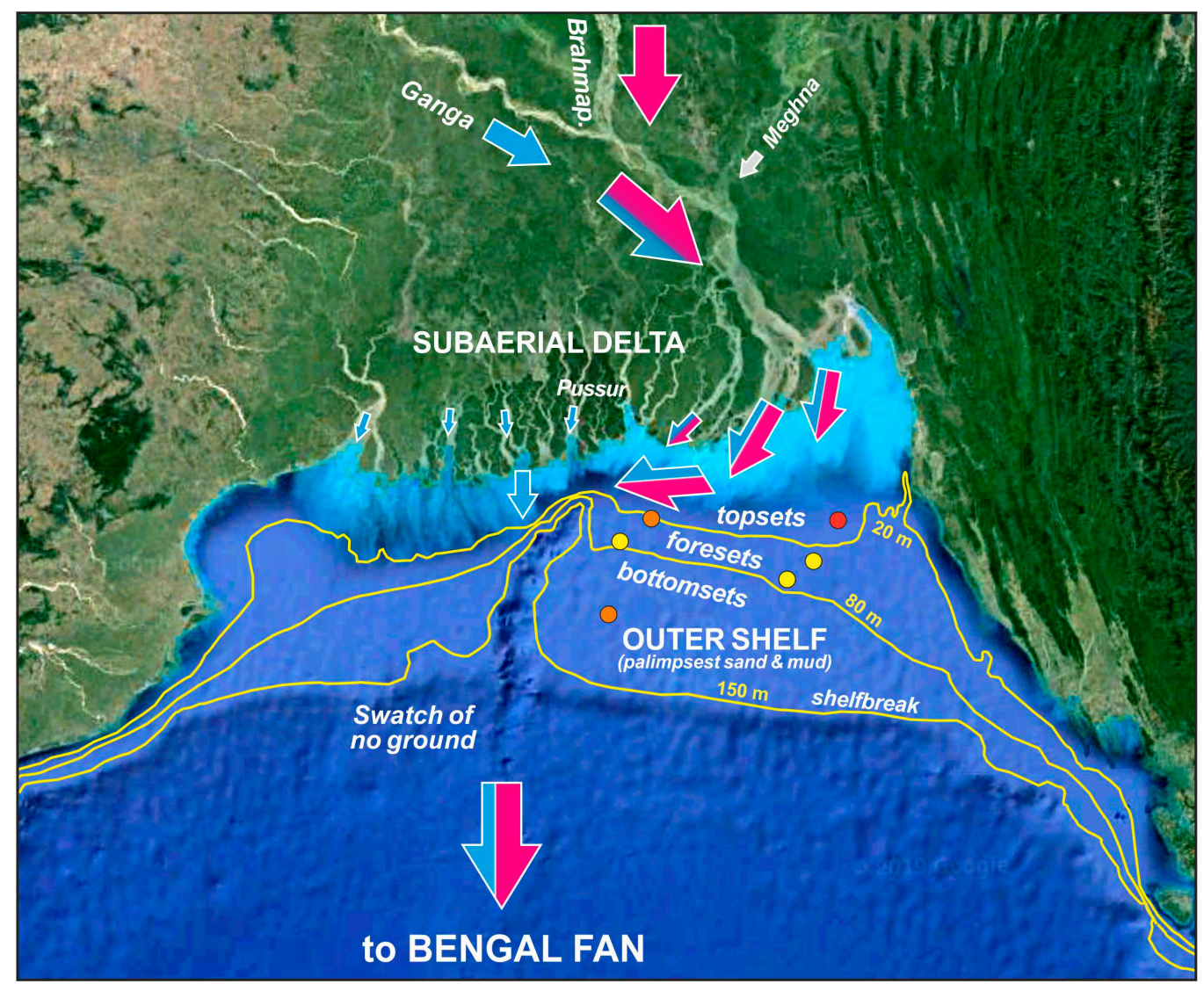

Figure 7. Sediment in transit across the Bengal system ([5-7]). Note the predominance of Brahmaputra (magenta) over Ganga (cyan) supply to the Meghna estuary and subaqueous delta. The subaerial delta, built by the Ganga River and progressively abandoned during the late Holocene highstand is now undergoing tidal reworking and locally net erosion, thus contributing mostly mud originally deposited by the Ganga River to the western part of the subaqueous delta. The studied sand and sandy silt samples are color-coded according to grain size as in Figure 1. 


\subsection{From the Bengal Shelf to the Bengal-Nicobar Fan}

Neogene Bengal Fan turbidites display litho-feldspatho-quartzose metamorphiclastic composition with hornblende-dominated heavy-mineral assemblages ([20,21]), comparing closely with modern Brahmaputra and Meghna estuary sediments and, thus, indicating continuous supply from the Ganga-Brahmaputra sediment system and dominant Himalayan provenance since the Miocene $([4,142,143])$. The mineralogy of upper Quaternary silty turbidites cored at ODP Sites 717-719 ([22]) is very close to that of Meghna estuary sediments (Figure 6), documenting a remarkable compositional homogeneity of the fluvio-deltaic to deep-sea-fan depositional system over $\sim 3000 \mathrm{~km}$, from Bangladesh to the equatorial Indian Ocean.

Additional detritus from the Indian subcontinent is, however, indicated in clay-rich intervals deposited during periods when turbidite channels shifted eastward ([22]). This is confirmed by geochemical data on uppermost Quaternary sediments of the western Bay of Bengal ([144]) and by the occurrence of olivine-which is rare in Meghna estuary sediments-in upper Pleistocene distal-fan turbidites, suggesting supply from Deccan Trap basalts via the Godavari and Krishna rivers ([145]).

Nicobar Fan turbidites also display feldspatho-quartzose to litho-feldspatho-quartzose metamorphiclastic detrital modes and mostly moderately rich amphibole-epidote-garnet tHM suites that compare closely with those of Meghna estuary and Bengal shelf sediments (Figure 3), confirming that they also belong to the colossal Bengal sediment system ([23]). The abundance of feldspar and the very close similarity of amphibole-epidote tHM suites of Bengal-Nicobar Fan turbidites with Brahmaputra River and Meghna estuary bedload (Figure 6) indicates a clear prevalence of Brahmaputra contribution lasting since the late Miocene and, thus, since the onset of rapid unroofing of the eastern Himalayan syntaxis ([146,147]).

A robust quantitative comparison among mineralogical assemblages, however, can be drawn only for sediments buried less than a few hundreds of meters, because the tHM suites of ancient strata are exposed to selective intrastratal dissolution of less durable minerals progressing with increasing age and burial depth ([148-150]). Heavy-mineral studies of Bengal Fan turbidites have documented the common occurrence of unstable pyroxene and olivine only in the upper part of the studied cores (i.e., Zone I of [22], dated as $\sim 0.5 \mathrm{Ma}$, burial depth $\leq 160 \mathrm{~m}$ b.s.f.). Ferromagnesian minerals including amphibole progressively decrease in the Pliocene and older sediments buried more than 250-300 m at DSDP Sites 211 and 218 ([20,151]), and the relative abundance of more durable zircon, tourmaline, rutile, and garnet consequently increases (correlation coefficients with core depth 0.54 to 0.72 , all significant at the 1\% level). Amphibole prevails over epidote + garnet in Quaternary strata (Zones I and IIa, burial depth $\leq 200 \mathrm{~m}$ b.s.f.), is less than both epidote and garnet in middle Miocene strata (Zone V, burial depth 650-750 m b.s.f.), to eventually become negligible in lower Miocene strata (Zone VI, burial depth $>750$ m b.s.f.; [22]).

\section{Conclusions}

This study adds new data and observations that, combined with extensive previous work, contributes to a better understanding and quantification of the enormous sediment flux that throughout the Neogene has transited across the Bengal basin and accumulated on Bengal Sea floors. Detritus mostly generated from rapid erosion of the active Himalayan orogen and entrained by the Ganga and Brahmaputra rivers, which joined two centuries ago to form the Meghna estuary, is partly stored in the subaqueous delta prograding onto the Bengal shelf, as in the subaerial delta formed by the Ganga River to the west and progressively abandoned during the late Holocene highstand.

From the Meghna estuary and the Bengal shelf all the way to the Bengal and Nicobar deep-sea fans, detritus is closer in composition to Brahmaputra sediments than to Ganga sediments, as testified by all mineralogical and geochemical parameters. Transparent heavy-mineral suites in sand and silt of the Meghna estuary, Bengal shelf, and Bengal-Nicobar Fans, as well as Sr and Nd isotope fingerprints ([17]), are virtually indistinguishable from those of Brahmaputra bedload and suspended load. Such a predominance over the Ganga is overemphasized because the Brahmaputra carries 
between $50 \%$ and $\geq 100 \%$ more Ca-plagioclase, epidote and heavy minerals in general, which together control most of the $\mathrm{Sr}$ and $\mathrm{Nd}$ budget in the sediment ([138]). A more balanced contribution from the two rivers is suggested by the most commonly cited estimates of their suspended loads as well as by bulk-sediment mineralogy and geochemistry, which converge to indicate that the Ganga may supply as much as $40 \%$ of the total sediment flux. We conclude that, although the Brahmaputra River supplies no less than two-thirds of the sand, Ganga contribution may be more significant for finer silt fractions and clay. This is because the Ganga River, having lower flow velocity and competence, entrains finer particles than the Brahmaputra at all channel depths $([8,14])$, and also because the subaerial delta actively formed by the Ganga until a few ka ago is presently undergoing tidal reworking and erosion $([6,66])$, thus contributing fine material to the western part of the active subaqueous delta ([19]). Although denser minerals tend to be segregated in coastal and shallow-marine environments, and slow-settling platy micas and clay are effectively winnowed and accumulated offshore, the studied shelf sediments never display the strong hydraulic-sorting effects observed in fluvial, estuarine, and beach sediments, reflecting the prevalence of depositional processes in the prograding subaqueous delta.

Although the Ganga and Brahmaputra drain also different geological domains, the Indian shield and the Trans-Himalayan batholiths and suture zone, respectively, the two rivers receive a large amount of detritus from the same Himalayan rock units. As a consequence, their sediments have mineralogical and, therefore, geochemical signatures that, although distinct, are not different enough to allow very precise estimates of their relative detrital supply. The task is made particularly difficult by the superposed effects of physical and chemical processes, which can produce a marked distortion of provenance signals. Hydraulic-sorting bias tends to efface any potential for distinction based on the geochemistry of bedload. Together with clay-mineral assemblages, geochemical data instead provide precious information on weathering conditions, highlighting not only the different intensity but also the different processes of weathering in Ganga and Brahmaputra lowlands. Ganga sediments undergo stronger alteration during more prolonged storage in the wider foreland basin. The Brahmaputra, instead, is chiefly a physical system, and yet the huge runoff leads to virtually complete dissolution of carbonate grains in bedload, whereas very little calcite and some dolomite is preserved in suspended load. Chemical dissolution becomes a much harder obstacle in the quantitative provenance assessment of ancient sediments, because unstable ferromagnesian minerals are selectively dissolved during burial diagenesis and the original mineralogical and geochemical fingerprints are thus progressively blurred in older strata. Nonetheless, the experience obtained from modern settings remains a fundamental aid to investigate the relative role played by climate and rainfall versus tectonically sustained relief in controlling the intensity of erosive processes across an active orogenic belt such as the Himalaya.

Supplementary Materials: The following are available online at http://www.mdpi.com/2075-163X/9/10/642/s1, Table S1: Information on the location of studied samples, Table S2: Petrographic dataset, Table S3: Heavy-mineral dataset, Table S4: Geochemical dataset, Table S5: Analytical uncertainties. The Google-Earth ${ }^{\mathrm{TM}}$ map of the sampling sites file, Bengalsand.kmz, is also provided.

Author Contributions: Project design and writing: E.G.; Petrographic analyses: G.V.; Heavy mineral analyses: S.A., M.L., and L.B.; Geochemical analyses: C.F.-L.

Funding: Funding was provided by Projects MIUR-PRIN 2015EC9PJ5 “The Subduction and Exhumation of the Continental Lithosphere: Their Effects on the Structure and Evolution of the Orogens" and MIUR-Dipartimenti di Eccellenza 2018-2022, Department of Earth and Environmental Sciences, University of Milano-Bicocca.

Acknowledgments: The article benefited from critical comments by two anonymous reviewers. Alberto Resentini carried out multidimensional scaling statistical analysis. We warmly thank Hermann Kudrass (BGR Hannover) for providing samples from Sonne campaigns SO93 and SO188. Yani Najman, Ruth Allen, and Andy Carter kindly shared samples S3562 and S3623.

Conflicts of Interest: The authors declare no conflict of interest. 


\section{References}

1. Milliman, J.D.; Syvitski, J.P.M. Geomorphic/tectonic control of sediment discharge to the ocean: The importance of small mountainous rivers. J. Geol. 1992, 100, 525-544. [CrossRef]

2. Goodbred, S.L.; Kuehl, S.A. Enormous Ganges-Brahmaputra sediment discharge during strengthened early Holocene monsoon. Geology 2000, 28, 1083-1086. [CrossRef]

3. Curray, J.R.; Emmel, F.J.; Moore, D.G. The Bengal Fan: Morphology, geometry, stratigraphy, history and processes. Marine Petrol. Geol. 2003, 19, 1191-1223. [CrossRef]

4. France-Lanord, C.; Spiess, V.; Klaus, A.; Schwenk, T.; Expedition 354 Scientists. Expedition 354 summary. In Proceedings of the International Ocean Discovery Program 354, Colombo, Sri Lanka, 29 January-31 March 2015; pp. 1-35.

5. Kuehl, S.A.; Allison, M.A.; Goodbred, S.L.; Kudrass, H. The Ganges-Brahmaputra Delta. In River Deltas-Concepts, Models, and Examples; Giosan, L., Bhattacharya, J.P., Eds.; SEPM Special Publication 83; SEPM: Tulsa, OK, USA, 2005; pp. 413-434.

6. Wilson, C.A.; Goodbred, S.L. Construction and maintenance of the Ganges-Brahmaputra-Meghna Delta: Linking process, morphology, and stratigraphy. Annu. Rev. Mar. Sci. 2015, 7, 67-88. [CrossRef] [PubMed]

7. Kudrass, H.R.; Machalett, B.; Palamenghi, L.; Meyer, I.; Zhang, W. Sediment transport by tropical cyclones recorded in a submarine canyon off Bangladesh. Geo Mar. Lett. 2018, 38, 481-496. [CrossRef]

8. Galy, V.; France-Lanord, C.; Beyssac, O.; Faure, P.; Kudrass, H.; Palhol, F. Efficient organic carbon burial in the Bengal fan sustained by the Himalayan erosional system. Nature 2007, 450, 407. [CrossRef]

9. Garzanti, E.; Vezzoli, G.; Andò, S.; France-Lanord, C.; Singh, S.K.; Foster, G. Sand petrology and focused erosion in collision orogens: The Brahmaputra case. Earth Planet. Sci. Lett. 2004, 220, 157-174. [CrossRef]

10. Garzanti, E.; Vezzoli, G.; Andò, S.; Lavé, J.; Attal, M.; France-Lanord, C.; DeCelles, P. Quantifying sand provenance and erosion (Marsyandi River, Nepal Himalaya). Earth Planet. Sci. Lett. 2007, 258, 500-515. [CrossRef]

11. Garzanti, E.; Andò, S.; Vezzoli, G. Settling-equivalence of detrital minerals and grain-size dependence of sediment composition. Earth Planet. Sci. Lett. 2008, 273, 138-151. [CrossRef]

12. Garzanti, E.; Andò, S.; France-Lanord, C.; Vezzoli, G.; Censi, P.; Galy, V.; Najman, Y. Mineralogical and chemical variability of fluvial sediments: 1 . Bedload sand (Ganga-Brahmaputra, Bangladesh). Earth Planet. Sci. Lett. 2010, 299, 368-381. [CrossRef]

13. Garzanti, E.; Andò, S.; France-Lanord, C.; Censi, P.; Vignola, P.; Galy, V.; Lupker, M. Mineralogical and chemical variability of fluvial sediments. 2. Suspended-load silt (Ganga-Brahmaputra, Bangladesh). Earth Planet. Sci. Lett. 2011, 302, 107-120. [CrossRef]

14. Lupker, M.; France-Lanord, C.; Lavé, J.; Bouchez, J.; Galy, V.; Métivier, F.; Gaillardet, J.; Lartiges, B.; Mugnier, J.L. A Rouse-based method to integrate the chemical composition of river sediments: Application to the Ganga basin. J. Geophys. Res. Earth Surf. 2011, 116, 1-24. [CrossRef]

15. Lupker, M.; France-Lanord, C.; Galy, V.; Lavé, J.; Gaillardet, J.; Gajurel, A.P.; Guilmette, C.; Rahman, M.; Singh, S.K.; Sinha, R. Predominant floodplain over mountain weathering of Himalayan sediments (Ganga basin). Geochim. Cosmochim. Acta 2012, 84, 410-432. [CrossRef]

16. Lupker, M.; Blard, P.H.; Lavé, J.; France-Lanord, C.; Leanni, L.; Puchol, N.; Charreau, J.; Bourlès, D. ${ }^{10} \mathrm{Be}$-derived Himalayan denudation rates and sediment budgets in the Ganga basin. Earth Planet. Sci. Lett. 2012, 333-334, 146-156. [CrossRef]

17. Lupker, M.; France-Lanord, C.; Galy, V.; Lavé, J.; Kudrass, H. Increasing chemical weathering in the Himalayan system since the Last Glacial Maximum. Earth Planet. Sci. Lett. 2013, 365, 243-252. [CrossRef]

18. Lupker, M.; Lavé, J.; France-Lanord, C.; Christl, M.; Bourlès, D.; Carcaillet, J.; Maden, C.; Wieler, R.; Rahman, M.; Bezbaruah, D.; et al. ${ }^{10}$ Be systematics in the Tsangpo-Brahmaputra catchment: The cosmogenic nuclide legacy of the eastern Himalayan syntaxis. Earth Surf. Dyn. 2017, 5, 429-449. [CrossRef]

19. Borromeo, L.; Andò, S.; France-Lanord, C.; Hahn, A.; Coletti, G.; Garzanti, E. Provenance of Bengal Shelf Sediments: 1. Mineralogy of Silt. Minerals 2019, 9, 640. [CrossRef]

20. Thompson, R.W. Mineralogy of sands from the Bengal and Nicobar fans, Sites 218 and 211, Eastern Indian Ocean; Initial Reports DSDP 22; U.S. Government Printing Office: Washington, DC, USA, 1974; pp. 711-713.

21. Ingersoll, R.V.; Suczek, C.A. Petrology and provenance of Neogene sand from Nicobar and Bengal Fans, DSDP Sites 211 and 218. J. Sediment. Petrol. 1979, 49, 1217-1228. 
22. Yokoyama, K.; Amano, K.; Taira, A.; Saito, Y. Mineralogy of silts from the Bengal Fan; Proc. ODP Sci. Results; Texas A\&M University: College Station, TX, USA, 1990; Volume 116, pp. 59-73.

23. Pickering, K.T.; Carter, A.; Andò, S.; Garzanti, E.; Limonta, M.; Vezzoli, G.; Milliken, K.L.; Chemale, F.; Pouderoux, H.; Kutterolfn, S.; et al. Sediment provenance of the Nicobar Submarine Fan, Indian Ocean. Earth Planet. Sci. Lett. 2019, in press.

24. Galy, A.; France-Lanord, C. Weathering processes in the Ganges-Brahmaputra basin and the riverine alkalinity budget. Chem. Geol. 1999, 159, 31-60. [CrossRef]

25. Galy, A.; France-Lanord, C.; Derry, L.A. The strontium isotopic budget of Himalayan rivers in Nepal and Bangladesh. Geochim. Cosmochim. Acta 1999, 63, 1905-1925. [CrossRef]

26. Garzanti, E. Stratigraphy and sedimentary history of the Nepal Tethys Himalayan passive margin. J. Asian Earth Sci. 1999, 17, 805-827. [CrossRef]

27. Sciunnach, D.; Garzanti, E. Subsidence history of the Tethys Himalaya. Earth Sci. Rev. 2012, 25, $179-198$. [CrossRef]

28. Colchen, M.; Le Fort, P.; Pêcher, A. Annapurna, Manaslu, Ganesh Himal; Editions du C.N.R.S.: Paris, France, 1986; 136p.

29. Carosi, R.; Montomoli, C.; Iaccarino, S. 20 years of geological mapping of the metamorphic core across Central and Eastern Himalayas. Earth Sci. Rev. 2017, 177, 124-138. [CrossRef]

30. Sakai, H. Rifting of the Gondwanaland and uplifting of the Himalayas recorded in Mesozoic and Tertiary fluvial sediments in the Nepal Himalayas. In Sedimentary Facies in the Active Plate Margin; Taira, A., Masuda, F., Eds.; Terra Scientific Publications: Tokyo, Japan, 1989; pp. 723-732.

31. DeCelles, P.G.; Robinson, D.M.; Quade, J.; Ojha, T.P.; Garzione, C.N.; Copeland, P.; Upreti, B.N. Stratigraphy, structure, and tectonic evolution of the Himalayan fold-thrust belt in western Nepal. Tectonics 2001, 20, 487-509. [CrossRef]

32. DeCelles, P.G.; Gehrels, G.E.; Quade, J.; Ojha, T.P.; Kapp, P.A.; Upreti, B.N. Neogene foreland basin deposits, erosional unroofing, and the kinematic history of the Himalayan fold-thrust belt, western Nepal Siwaliks. Geol. Soc. Am. Bull. 1998, 110, 2-21. [CrossRef]

33. Garzanti, E. The Himalayan foreland basin from collision onset to the present: A sedimentary-petrology perspective. In Himalayan Tectonics: A Modern Synthesis; Treloar, P., Searle, M.P., Eds.; Geological Society: London, UK, 2019; Special Publication 483; pp. 65-122. [CrossRef]

34. Zhu, D.C.; Zhao, Z.D.; Niu, Y.L.; Mo, X.X.; Chung, S.L.; Hou, Z.Q.; Wang, L.Q.; Wu, F.Y. The Lhasa terrane: Record of a microcontinent and its histories of drift and growth. Earth Planet. Sci. Lett. 2011, 301, 241-255. [CrossRef]

35. Hébert, R.; Bezard, R.; Guilmette, C.; Dostal, J.; Wang, C.S.; Liu, Z.F. The Indus-Yarlung Zangbo ophiolites from Nanga Parbat to Namche Barwa syntaxes, southern Tibet: First synthesis of petrology, geochemistry, and geochronology with incidences on geodynamic reconstructions of Neo-Tethys. Gondwana Res. 2012, 22, 377-397. [CrossRef]

36. An, W.; Hu, X.; Garzanti, E. Sandstone provenance and tectonic evolution of the Xiukang Mélange from Neotethyan subduction to India-Asia collision (Yarlung-Zangbo suture). Gondwana Res. 2017, 41, 222-234. [CrossRef]

37. Wang, J.-G.; Hu, X.M.; Garzanti, E.; An, W.; Liu, X.-C. The birth of the Xigaze forearc basin in southern Tibet. Earth Planet. Sci. Lett. 2017, 465, 38-47. [CrossRef]

38. Gansser, A. The Peri-Indian suture zone. In Géologie des Châines Alpines Issues de la Téthys; Auboin, J., Debelmas, J., Latreille, M., Eds.; Mémoires B.R.G.M.: Paris, France, 1980; Volume 115, pp. 140-148.

39. Burg, J.P.; Nievergelt, P.; Oberli, F.; Seward, D.; Davy, P.; Maurin, J.C.; Diao, Z.; Meier, M. The Namche Barwa syntaxis: Evidence for exhumation related to compressional crustal folding. J. Asian Earth Sci. 1998, 16, 239-252. [CrossRef]

40. Zeitler, P.K.; Meltzer, A.S.; Koons, P.O.; Craw, D.; Hallet, B.; Chamberlain, C.P.; Kidd, W.S.F.; Park, S.K.; Seeber, L.; Bishop, M.; et al. Erosion, Himalayan geodynamics, and the geomorphology of metamorphism. GSA Today 2001, 11, 4-9. [CrossRef]

41. Gemignani, L.; van der Beek, P.; Braun, J.; Najman, Y.; Bernet, M.; Garzanti, E.; Wijbrans, J.R. Downstream evolution of the thermochronologic age signal in the Brahmaputra catchment (eastern Himalaya): Implications for the detrital record of erosion. Earth Planet. Sci. Lett. 2018, 499, 48-61. [CrossRef] 
42. Gansser, A. Geology of the Bhutan Himalaya; Denkschriften der Schweizerischen Naturforschenden Geselschaft; Birkhäuser Verlag: Basel, Switzerland, 1983; 181p.

43. Kumar, G. Geology of Arunachal Pradesh; Geological Society of India: Bengaluru, India, 1997; 217p.

44. Long, S.P.; McQuarrie, N.; Tobgay, T.; Grujic, D.; Hollister, L. Geologic map of Bhutan. J. Maps $2011,7$. [CrossRef]

45. Allison, M.A.; Kuehl, S.A.; Martin, T.C.; Hassan, A. Importance of flood-plain sedimentation for river sediment budgets and terrigenous input to the oceans: Insights from the Brahmaputra-Jamuna River. Geology 1998, 26, 175-178. [CrossRef]

46. Delft Hydraulics. River Survey Project, Flood Action Plan 24, Special Report $\mathrm{n}^{\circ} 18$. In Sediment Rating Curves and Balances; Water Resources Planning Organization: Dhaka, Bangladesh, 1996.

47. Hay, W.W. Detrital sediment fluxes from continents to oceans. Chem. Geol. 1998, 145, 287-323. [CrossRef]

48. Islam, M.R.; Begum, S.F.; Yamaguchi, Y.; Ogawa, K. The Ganges and Brahmaputra rivers in Bangladesh: Basin denudation and sedimentation. Hydrol. Process. 1999, 13, 2907-2923. [CrossRef]

49. Bookhagen, B.; Burbank, D.W. Topography, relief, and TRMM-derived rainfall variations along the Himalaya. Geophys. Res. Lett. 2006, 33, L08405. [CrossRef]

50. Coleman, J.M. Brahmaputra River: Channel processes and sedimentation. Sediment. Geol. 1969, 3, $129-239$. [CrossRef]

51. Whitaker, D.W.; Wasimi, S.A.; Islam, S. The El Niño-southern oscillation and long-range forecasting of flows in the Ganges. Int. J. Climatol. 2001, 21,77-87. [CrossRef]

52. Singh, I.B. The Ganga River. In Large Rivers: Geomorphology and Management; Gupta, A., Ed.; Wiley: Chichester, UK, 2007; pp. 347-371.

53. Singh, S.K. Erosion and weathering in the Brahmaputra River system. In Large Rivers: Geomorphology and Management; Wiley: Chichester, UK, 2007; pp. 373-393.

54. Best, J.L.; Ashworth, P.J.; Sarker, M.H.; Roden, J.E. The Brahmaputra-Jamuna River, Bangladesh. In Large Rivers: Geomorphology and Management; Gupta, A., Ed.; Wiley: New York, NY, USA, 2007; pp. 395-433.

55. Goodbred, S.L.; Paolo, P.M.; Ullah, M.S.; Pate, R.D.; Khan, S.R.; Kuehl, S.A.; Singh, S.K.; Rahaman, W. Piecing together the Ganges-Brahmaputra-Meghna River delta: Use of sediment provenance to reconstruct the history and interaction of multiple fluvial systems during Holocene delta evolution. Geol. Soc. Am. Bull. 2014, 126, 1495-1510. [CrossRef]

56. Rennell, J.J. An Actual Survey of the Provinces of BENGAL, BAHAR etc. by Major General James Rennell, Surveyor to the Honourable East India Company in Bengal, 1776; Faden, W., Ed.; Geographer to the King, Charing Cross; East India Company: London, UK, 1786.

57. Bristow, C.S. Avulsion, river metamorphosis and reworking by underfit streams: A modern example from the Brahmaputra River in Bangladesh and a possible ancient example in the Spanish Pyrenees. In Fluvial Sedimentology 6; Smith, N.D., Rogers, J., Eds.; Special Publication of the International Association of Sedimentologists: Devon, UK, 1999; Volume 28, pp. 221-230.

58. Pickering, J.L.; Goodbred, S.L.; Reitz, M.D.; Hartzog, T.H.; Mondal, D.R.; Hossain, M.S. Late Quaternary sedimentary record and Holocene channel avulsions of the Jamuna and Old Brahmaputra River valleys in the upper Bengal delta plain. Geomorphology 2014, 227, 123-136. [CrossRef]

59. Alam, M.; Alam, M.M.; Curray, J.R.; Chowdhury, M.L.R.; Gani, M.R. An overview of the sedimentary geology of the Bengal Basin in relation to the regional tectonic framework and basin-fill history. Sediment. Geol. 2003, 155, 179-208. [CrossRef]

60. Najman, Y.; Bickle, M.; BouDagher-Fadel, M.; Carter, A.; Garzanti, E.; Paul, M.; Wijbrans, J.; Willett, E.; Oliver, G.; Parrish, R.; et al. The Paleogene record of Himalayan erosion: Bengal Basin, Bangladesh. Earth Planet. Sci. Lett. 2008, 273, 1-14. [CrossRef]

61. Najman, Y.; Allen, R.; Willett, E.A.F.; Carter, A.; Barfod, D.; Garzanti, E.; Wijbrans, J.; Bickle, M.J.; Vezzoli, G.; Andò, S.; et al. The record of Himalayan erosion preserved in the sedimentary rocks of the Hatia Trough of the Bengal Basin and the Chittagong Hill Tracts, Bangladesh. Basin Res. 2012, 24, 1-21. [CrossRef]

62. Brown, S.; Nicholls, R.J. Subsidence and human influences in mega deltas: The case of the GangesBrahmaputra-Meghna. Sci. Total Environ. 2015, 527-528, 362-374. [CrossRef]

63. Grall, C.; Steckler, M.S.; Pickering, J.L.; Goodbred, S.; Sincavage, R.; Paola, C.; Akhter, S.H.; Spiess, V. A base-level stratigraphic approach to determining Holocene subsidence of the Ganges-Meghna-Brahmaputra Delta plain. Earth Planet. Sci. Lett. 2018, 499, 23-36. [CrossRef] 
64. Goodbred, S.L.; Kuehl, S.A.; Steckler, M.S.; Sarker, M.H. Controls on facies distribution and stratigraphic preservation in the Ganges-Brahmaputra delta sequence. Sediment. Geol. 2003, 155, 301-316. [CrossRef]

65. Allison, M.A.; Khan, S.R.; Goodbred, S.L.; Kuehl, S.A. Stratigraphic evolution of the late Holocene Ganges-Brahmaputra lower delta plain. Sediment. Geol. 2003, 155, 317-342. [CrossRef]

66. Allison, M.A. Historical changes in the Ganges-Brahmaputra delta front. J. Coast. Res. 1998, 14, $1269-1275$.

67. Palamenghi, L.; Schwenk, T.; Spies, V.; Kudrass, H.R. Seismostratigraphic analysis with centennial to decadal time resolution of the sediment sink in the Ganges-Brahmaputra subaqueous delta. Cont. Shelf Res. 2011, 31, 712-730. [CrossRef]

68. Michels, K.H.; Kudrass, H.R.; Hubscher, C.; Suckow, A.; Wiedicke, M. The submarine delta of the Ganges-Brahmaputra: Cyclone-dominated sedimentation patterns. Mar. Geol. 1998, 149, 133-154. [CrossRef]

69. Hübscher, C.; Spiess, V. Forced regression systems tracts on the Bengal Shelf. Mar. Geol. 2005, 219, $207-218$. [CrossRef]

70. Murty, T.S.; Henry, R.F. Tides in the Bay of Bengal. J. Geophys. Res. 1983, 88, 6069-6076. [CrossRef]

71. Islam, T.; Peterson, R.E. Climatology of landfalling tropical cyclones in Bangladesh 1877-2003. Nat. Hazards 2009, 48, 115-135. [CrossRef]

72. Hossain, M.D.; Aucoin, J. George Harrison and the Concert for Bangladesh: When rock music forever fused with politics on a World stage. In Music as a Platform for Political Communication; IGI Global: Pennsylvania, PA, USA, 2017; pp. 149-166.

73. Goodbred, S.L.; Kuehl, S.A. The significance of large sediment supply, active tectonism, and eustasy on margin sequence development: Late Quaternary stratigraphy and evolution of the Ganges—Brahmaputra delta. Sediment. Geol. 2000, 133, 227-248. [CrossRef]

74. Kuehl, S.A.; Levy, B.M.; Moore, W.S.; Allison, M.A. Subaqueous delta of the Ganges-Brahmaputra river system. Mar. Geol. 1997, 144, 81-96. [CrossRef]

75. Rogers, K.G.; Goodbred, S.L.; Khan, S.R. Shelf-to-canyon connections: Transport-related morphology and mass balance at the shallow-headed, rapidly aggrading Swatch of No Ground (Bay of Bengal). Mar. Geol. 2015, 369, 288-299. [CrossRef]

76. Kudrass, H.R.; Spiess, V.; Bruns, A.; Ding, F.; Fekete, N.; Fenner, J.; France-Lanord, C.; Palamenghi, L.; Reinhardt, L.; Rühlemann, C.; et al. Cruise Report SO 188-2 Chittagong (Bangladesh)_Penang (Malaysia) 06.07.2006-31.07.2006; BGR: Hannover, Germany, 2007; pp. 1-100.

77. Kudrass, H.R.; Scientific Shipboard Party. Cruise Report SO93/1-3 Bengal Fan; Bundesanstalt für Geowissenschaften und Rohstoffe: Hannover, Germany, 1994; 135p.

78. Vermeesch, P. Multi-sample comparison of detrital age distributions. Chem. Geol. 2013, 341, $140-146$. [CrossRef]

79. Vermeesch, P.; Garzanti, E. Making geological sense of 'Big Data' in sedimentary provenance analysis. Chem. Geol. 2015, 409, 20-27. [CrossRef]

80. Gabriel, K.R. The biplot graphic display of matrices with application to principal component analysis. Biometrika 1971, 58, 453-467. [CrossRef]

81. Ingersoll, R.V.; Bullard, T.F.; Ford, R.L.; Grimm, J.P.; Pickle, J.D.; Sares, S.W. The effect of grain size on detrital modes: A test of the Gazzi-Dickinson point-counting method. J. Sediment. Petrol. 1984, 54, 103-116.

82. Crook, K.A.W. Classification of arenites. Am. J. Sci. 1960, 258, 419-428. [CrossRef]

83. Dickinson, W.R. Interpreting detrital modes of graywacke and arkose. J. Sediment. Petrol. 1970, 40, 695-707.

84. Garzanti, E. From static to dynamic provenance analysis-Sedimentary petrology upgraded. Sediment. Geol. 2016, 336, 3-13. [CrossRef]

85. Garzanti, E. Petrographic classification of sand and sandstone. Earth Sci. Rev. 2019, 192, 545-563. [CrossRef]

86. Garzanti, E.; Vezzoli, G. A classification of metamorphic grains in sands based on their composition and grade. J. Sediment. Res. 2003, 73, 830-837. [CrossRef]

87. Galehouse, J.S. Point counting. In Procedures in Sedimentary Petrology; Carver, R.E., Ed.; Wiley: New York, NY, USA, 1971; pp. 385-407.

88. Andò, S.; Garzanti, E. Raman spectroscopy in heavy-mineral studies. Geol. Soc. Lond. Spec. Publ. 2014, 386, 395-412. [CrossRef]

89. Garzanti, E.; Andò, S. Heavy-mineral concentration in modern sands: Implications for provenance interpretation. In Heavy Minerals in Use; Mange, M.A., Wright, D.T., Eds.; Developments in Sedimentology Series 58; Elsevier: Amsterdam, The Netherlands, 2007; pp. 517-545. 
90. Garzanti, E.; Andò, S. Heavy Minerals for Junior Woodchucks. Minerals 2019, 9, 148. [CrossRef]

91. Garzanti, E. The maturity myth in sedimentology and provenance analysis. J. Sediment. Res. 2017, 87, 353-365. [CrossRef]

92. Hubert, J.F. A zircon-tourmaline-rutile maturity index and the interdependence of the composition of heavy mineral assemblages with the gross composition and texture of sandstones. J. Sediment. Petrol. 1962, 32, 440-450.

93. Govindaraju, K.; Mevelle, G. Fully automated dissolution and separation methods for inductively coupled plasma atomic emission spectrometry rock analysis. Application to the determination of rare earth elements. Plenary lecture. J. Anal. Atomic Spectrom. 1987, 2, 615-621. [CrossRef]

94. Carignan, J.; Hild, P.; Mevelle, G.; Morel, J.; Yeghicheyan, D. Routine analyses of trace elements in geological samples using flow injection and low pressure on-line liquid chromatography coupled to ICP-MS: A study of geochemical reference materials BR, DR-N, UB-N, AN-G and GH. Geostand. Newsl. 2001, 25, 187-198. [CrossRef]

95. Nesbitt, H.W.; Young, G.M. Early Proterozoic climates and plate motions inferred from major element chemistry of lutites. Nature 1982, 299, 715-717. [CrossRef]

96. Parker, A. An index of weathering for silicate rocks. Geol. Mag. 1970, 107, 501-504. [CrossRef]

97. Colin, C.; Turpin, L.; Bertaux, J.; Desprairies, A.; Kissel, C. Erosional history of the Himalayan and Burman ranges during the last two glacial-interglacial cycles. Earth Planet. Sci. Lett. 1999, 171, 647-660. [CrossRef]

98. Garzanti, E.; Padoan, M.; Andò, S.; Resentini, A.; Vezzoli, G.; Lustrino, M. Weathering and relative durability of detrital minerals in equatorial climate: Sand petrology and geochemistry in the East African Rift. J. Geol. 2013, 121, 547-580. [CrossRef]

99. Garzanti, E.; Padoan, M.; Setti, M.; Peruta, L.; Najman, Y.; Villa, I.M. Weathering geochemistry and Sr-Nd fingerprints of equatorial upper Nile and Congo muds. Geochem. Geophys. Geosyst. 2013, 14, 292-316. [CrossRef]

100. Singh, S.K.; Rai, S.K.; Krishnaswami, S. Sr and Nd isotopes in river sediments from the Ganga Basin: Sediment provenance and spatial variability in physical erosion. J. Geophys. Res. Earth Surf. 2008, 113, F03006. [CrossRef]

101. Gaillardet, J.; Dupré, B.; Allègre, C.J. Geochemistry of large river suspended sediments: Silicate weathering or recycling tracer? Geochim. Cosmochim. Acta 1999, 63, 4037-4051. [CrossRef]

102. Taylor, S.R.; McLennan, S.M. The geochemical evolution of the continental crust. Rev. Geophys. 1995, 33, 241-265. [CrossRef]

103. Rudnick, R.L.; Gao, S. Composition of the continental crust. In Treatise on Geochemistry, The Crust; Rudnick, R.L., Holland, H.D., Turekian, K.K., Eds.; Elsevier Pergamon: Oxford, UK, 2003; Volume 3, pp. 1-64.

104. Garzanti, E.; Resentini, A. Provenance control on chemical indices of weathering (Taiwan river sands). Sediment. Geol. 2016, 336, 81-95. [CrossRef]

105. Garzanti, E.; Andò, S. Plate tectonics and heavy-mineral suites of modern sands. In Heavy Minerals in Use; Mange, M.A., Wright, D.T., Eds.; Developments in Sedimentology Series 58; Elsevier: Amsterdam, The Netherlands, 2007; pp. 741-763.

106. Comas-Cufí, M.; Thió-Henestrosa, F.S. CoDaPack 2.0: A stand-alone, multi-platform compositional software. In Proceedings of the 4th International Workshopon Compositional Data Analysis, Sant Feliu de Guíxols, Spain, 10-13 May 2011.

107. Singh, S.K.; France-Lanord, C. Tracing the distribution of erosion in the Brahmaputra watershed from isotopic compositions of stream sediments. Earth Planet. Sci. Lett. 2002, 202, 645-662. [CrossRef]

108. Galy, V.; France-Lanord, C.; Lartiges, B. Loading and fate of riverine particulate organic carbon from the Himalaya to the Ganga-Brahmaputra delta. Geochim. Cosmochim. Acta 2008, 72, 1767-1787. [CrossRef]

109. Rouse, H. Modern conceptions of the mechanics of fluid turbulence. Trans. Am. Soc. Civ. Eng. 1937, 102, 463-543.

110. Vanoni, V.A. Sedimentation Engineering; Manuals and Reports in Engineering Practice; American Society of Civil Engineers: Reston, VA, USA, 2006; Volume 54, 418p.

111. Komar, P.D. The entrainment, transport and sorting of heavy minerals by waves and currents. In Heavy Minerals in Use; Mange, M.A., Wright, D.T., Eds.; Developments in Sedimentology Series; Elsevier: Amsterdam, The Netherlands, 2007; Volume 58, pp. 3-48. 
112. Garzanti, E.; Andò, S.; Vezzoli, G. Grain-size dependence of sediment composition and environmental bias in provenance studies. Earth Planet. Sci. Lett. 2009, 277, 422-432. [CrossRef]

113. Basu, A.; Bickford, M.E.; Deasy, R. Inferring tectonic provenance of siliciclastic rocks from their chemical compositions: A dissent. Sediment. Geol. 2016, 336, 26-35. [CrossRef]

114. Von Eynatten, H.; Tolosana-Delgado, R.; Karius, V. Sediment generation in modern glacial settings: Grain-size and source-rock control on sediment composition. Sediment. Geol. 2012, 280, 80-92. [CrossRef]

115. Garzanti, E.; Resentini, A.; Vezzoli, G.; Andò, S.; Malusà, M.G.; Padoan, M.; Paparella, P. Detrital fingerprints of fossil continental-subduction zones (Axial Belt Provenance, European Alps). J. Geol. 2010, 118, 341-362. [CrossRef]

116. McBride, M.B. Reactions controlling heavy metal solubility in soils. In Advances in Soil Science; Springer: New York, NY, USA, 1989; Volume 10, pp. 1-56.

117. Bostick, B.C.; Vairavamurthy, M.A.; Karthikeyan, K.G.; Chorover, J. Cesium adsorption on clay minerals: An EXAFS spectroscopic investigation. Environ. Sci. Technol. 2002, 36, 2670-2676. [CrossRef]

118. Shamsudduha, M.; Uddin, A.; Saunders, J.A.; Lee, M.K. Quaternary stratigraphy, sediment characteristics and geochemistry of arsenic-contaminated alluvial aquifers in the Ganges-Brahmaputra floodplain in central Bangladesh. J. Contam. Hydrol. 2008, 99, 112-136. [CrossRef] [PubMed]

119. Sengupta, R.; Basu, P.; Bandyopadhyay, R.; Bandyopadhyay, A.; Rakshit, S.; Sharma, B. Sediments in the Continental Shelf in and Around the Swatch of No Ground; Special Publications; Geological Survey of India: Kolkata, India, 1992; Volume 29, pp. 201-207.

120. Wiedicke, M.; Kudrass, H.R.; Hübscher, C. Oolitic beach barriers of the last Glacial sea-level lowstand at the outer Bengal shelf. Mar. Geol. 1999, 157, 7-18. [CrossRef]

121. Opdyke, B.N.; Wilkinson, B.H. Paleolatitude distribution of Phanerozoic marine ooids and cements. Palaeogeogr. Palaeoclimatol. Palaeoecol. 1990, 78, 135-148. [CrossRef]

122. Gallagher, S.J.; Reuning, L.; Himmler, T.; Henderiks, J.; De Vleeschouwer, D.; Groeneveld, J.; Rastegar Lari, A.; Fulthorpe, C.S.; Bogus, K.; Expedition 356 Shipboard Scientists. The enigma of rare Quaternary oolites in the Indian and Pacific Oceans: A result of global oceanographic physico-chemical conditions or a sampling bias? Quat. Sci. Rev. 2018, 200, 114-122. [CrossRef]

123. Garzanti, E.; Resentini, A.; Andò, S.; Vezzoli, G.; Vermeesch, P. Physical controls on sand composition and relative durability of detrital minerals during long-distance littoral and eolian transport (coastal Namibia). Sedimentology 2015, 62, 971-996. [CrossRef]

124. Resentini, A.; Andò, S.; Garzanti, E. Quantifying roundness of detrital minerals by image analysis: Sediment transport, shape effects, and provenance implications. J. Sediment. Res. 2018, 88, 276-289. [CrossRef]

125. Singh, S.K.; Sarin, M.M.; France-Lanord, C. Chemical erosion in the eastern Himalaya: Major ion composition of the Brahmaputra and $\delta^{13} \mathrm{C}$ of dissolved inorganic carbon. Geochim. Cosmochim. Acta 2005, 69, 3573-3588. [CrossRef]

126. Sarin, M.M.; Krishnaswami, S.; Dilli, K.; Somayajulu, B.L.K.; Moore, W.S. Major ion chemistry of the Ganga-Brahmaputra river system: Weathering processes and fluxes to the Bay of Bengal. Geochim. Cosmochim. Acta 1989, 53, 997-1009. [CrossRef]

127. Datta, D.K.; Subramanian, V. Texture and mineralogy of sediments from the Ganges-Brahmaputra-Meghna river system in the Bengal Basin, Bangladesh and their environmental implications. Environ. Geol. 1997, 30, 181-188. [CrossRef]

128. Heroy, D.C.; Kuehl, S.A.; Goodbred, S.L. Mineralogy of the Ganges and Brahmaputra Rivers: Implications for river switching and Late Quaternary climate change. Sediment. Geol. 2003, 155, 343-359. [CrossRef]

129. Huyghe, P.; Guilbaud, R.; Bernet, M.; Galy, A.; Gajurel, A.P. Significance of the clay mineral distribution in fluvial sediments of the Neogene to recent Himalayan foreland basin (west-central Nepal). Basin Res. 2011, 23, 332-345. [CrossRef]

130. Khan, M.H.R.; Liu, J.; Liu, S.; Seddique, A.A.; Cao, L.; Rahman, A. Clay mineral compositions in surface sediments of the Ganges-Brahmaputra-Meghna river system of Bengal Basin, Bangladesh. Mar. Geol. 2019, 412, 27-36. [CrossRef]

131. Garzanti, E.; Vermeesch, P.; Andò, S.; Botti, E.; Limonta, M.; Vezzoli, G.; Dinis, P.; Hahn, A.; Baudet, D.; De Grave, J.; et al. Congo River Sand and the Equatorial Quartz Factory. Earth Sci. Rev. 2019, 197, 102918. [CrossRef] 
132. Garzanti, E.; Vermeesch, P.; Padoan, M.; Resentini, A.; Vezzoli, G.; Andò, S. Provenance of passive-margin sand (southern Africa). J. Geol. 2014, 122, 17-42. [CrossRef]

133. Garzanti, E.; Padoan, M.; Setti, M.; López-Galindo, A.; Villa, I.M. Provenance versus weathering control on the composition of tropical river mud (southern Africa). Chem. Geol. 2014, 366, 61-74. [CrossRef]

134. Dinis, P.; Garzanti, E.; Vermeesch, P.; Huvi, J. Climatic zonation and weathering control on sediment composition (Angola). Chem. Geol. 2017, 467, 110-121. [CrossRef]

135. Dinis, P.A.; Garzanti, E.; Hahn, A.; Vermeesch, P.; Pinto, M.C. Weathering indices as climate proxies. A step forward based on Congo and SW African river muds. Earth Sci. Rev. 2019, in press.

136. Stumm, W.; Morgan, J.J. Aquatic Chemistry; John Wiley \& Sons: New York, NY, USA, 1996; 1022p.

137. Karim, A.; Veizer, J. Weathering processes in the Indus River Basin: Implications from riverine carbon, sulfur, oxygen, and strontium isotopes. Chem. Geol. 2000, 170, 153-177. [CrossRef]

138. Garçon, M.; Chauvel, C.; France-Lanord, C.; Limonta, M.; Garzanti, E. Which minerals control the $\mathrm{Nd}-\mathrm{Hf}-\mathrm{Sr}-\mathrm{Pb}$ isotopic compositions of river sediments? Chem. Geol. 2014, 364, 42-55. [CrossRef]

139. Garzanti, E.; Resentini, A.; Vezzoli, G.; Andò, S.; Malusà, M.; Padoan, M. Forward compositional modelling of Alpine orogenic sediments. Sediment. Geol. 2012, 280, 149-164. [CrossRef]

140. Resentini, A.; Goren, L.; Castelltort, S.; Garzanti, E. Partitioning the sediment flux by provenance and tracing erosion patterns in Taiwan. J. Geophys. Res. Earth Surf. 2017, 122. [CrossRef]

141. Vermeesch, P.; Resentini, A.; Garzanti, E. An R package for statistical provenance analysis. Sediment. Geol. 2016, 336, 14-25.

142. France-Lanord, C.; Derry, L.; Michard, A. Evolution of the Himalaya since Miocene time: Isotopic and sedimentological evidence from the Bengal Fan. Geol. Soc. Lond. Spec. Publ. 1993, 74, 603-621. [CrossRef]

143. Yoshida, K.; Cruz, J.W.; Osaki, A.; Masuda, A.; Manoj, M.C.; France-Lanord, C. Detrital heavy mineral record in the Bengal Fan constrains the evolution of the Himalaya and the linkage of the Ganga and Brahmaputra Rivers. In Proceedings of the American Geophysical Union, Fall Meeting 2018, Washington, DC, USA, 9-14 December 2018.

144. Tripathy, G.R.; Singh, S.K.; Ramaswamy, V. Major and trace element geochemistry of Bay of Bengal sediments: Implications to provenances and their controlling factors. Palaeogeogr. Palaeoclimatol. Palaeoecol. 2014, 397, 20-30. [CrossRef]

145. Subramanian, V.; Van't Dack, L.; Van Grieken, R. Chemical composition of river sediments from the Indian sub-continent. Chem. Geol. 1985, 48, 271-279. [CrossRef]

146. Zeitler, P.K.; Meltzer, A.S.; Brown, L.; Kidd, W.S.F.; Lim, C.; Enkelmann, E. Tectonics and topographic evolution of Namche Barwa and the easternmost Lhasa block, Tibet. In Toward an Improved Understanding of Uplift Mechanisms and the Elevation History of the Tibetan Plateau; Nie, J., Hoke, G.D., Horton, B.K., Eds.; Geological Society of America Special Papers; Geological Society of America: Bould, CO, USA, 2014; Volume 507, pp. 23-58.

147. Govin, G.; Najman, Y.; Dupont-Nivet, G.; Millar, I.; van der Beek, P.; Huyghe, P.; O'Sullivan, P.; Mark, C.; Vögeli, N. The tectonics and paleo-drainage of the easternmost Himalaya (Arunachal Pradesh, India) recorded in the Siwalik rocks of the foreland basin. Am. J. Sci. 2018, 318, 764-798. [CrossRef]

148. Morton, A.C.; Hallsworth, C. Stability of detrital heavy minerals during burial diagenesis. In Heavy Minerals in Use; Developments in Sedimentology Series; Mange, M.A., Wright, D.T., Eds.; Elsevier: Amsterdam, The Netherlands, 2007; Volume 58, pp. 215-245.

149. Andò, S.; Garzanti, E.; Padoan, M.; Limonta, M. Corrosion of heavy minerals during weathering and diagenesis: A catalog for optical analysis. Sediment. Geol. 2012, 280, 165-178. [CrossRef]

150. Garzanti, E.; Andò, S.; Limonta, M.; Fielding, L.; Najman, Y. Diagenetic control on mineralogical suites in sand, silt, and mud (Cenozoic Nile Delta): Implications for provenance reconstructions. Earth Sci. Rev. 2018, 185, 122-139. [CrossRef]

151. Mallik, T.K. Mineralogy of deep-sea sands of the Indian Ocean. Mar. Geol. 1978, 27, 161-176. [CrossRef]

(C) 2019 by the authors. Licensee MDPI, Basel, Switzerland. This article is an open access article distributed under the terms and conditions of the Creative Commons Attribution (CC BY) license (http://creativecommons.org/licenses/by/4.0/). 